\title{
THE SOUTH AMERICAN LIZARDS IN THE COLLECTION OF THE UNITED STATES NATIONAL MUSEUM
}

\author{
By Charles E. Burt and May Danheim Burt \\ of Trinity University, Waxahachie, Texas
}

\section{INTRODUCTION}

During the course of our recent study of the South American lizards ${ }^{1}$ we have examined the interesting collection contained in the United States National Museum. In it we find a new species from Argentina, which is described below as Plica stejnegeri, and numerous other specimens. Although the latter serve as representatives of previously described species, many of the variations and peculiarities are found to be of sufficient systematic importance to warrant an elaboration here. Moreover, many of the distributional records are new.

Recently Amaral (1925) has prepared an interesting and comprehensive account of the South American snakes in the collection of the United States National Museum, which we now follow with our contribution pertaining to the lizards.

We wish to express here our appreciation to Dr. L. Stejneger for permission to prepare this report and for the loan of valuable specimens, and to Miss Doris M. Cochran for placing every available facility at our disposal while we were at the United States National Museum. Furthermore, we are indebted to both for helpful criticisms and additions to the manuscript. The senior author is also indebted to the authorities of the American Museum of Natural History for permission to undertake this study while a staff member of that institution.

${ }^{1}$ Additional details pertaining to certain taxonomic modifications that are incorporated in the present report will be found a second contribution, entitled the "South American Lizards in the Collection of the American Museum of Natural History." This work will appear in a forthcoming issue of the Bulletin of the American Museum of Natural History.

No. 2849.-Proceedings U. S. National Museum, Vol. 78, Art. 6 $2609-30-1$ 


\section{Family GEKKONIDAE}

\section{Genus GONATODES Fitzinger \\ GONATODES ALBOGULARIS (Duméril and Bibron)}

1836. Gymnodactylus albogularis Duméril and Bibron, Erp. Gén., vol. 3, p. 415 (type locality, Martinique and Cuba).

1885. Gonatodes albogularis Boulenger, Cat. Liz. Brit. Mus., vol. 1, p. 59.

The writer agrees with Stejneger (1917) that the United States National Museum specimens from Curaçao, No. 13859 (seven individuals), collected February 10-18, 1884, by the United States Fish Commission steamer Albatross, should be referred to albogularis, rather than to fuscus or vittatus.

\section{GONATODES ARTRICUCULLARIS Noble}

1921. Gonatodes atricucullaris Noble, Ann. New York Acad. Sci., vol. 29, p. 135 (type locality, Bellavista, Peru).

Peru.-Eleven specimens, Nos. 64039-44 and 75941-45 (paratypes), collected at Bellavista by G. K. Noble.

\section{GONATODES VITTATUS (Lichtenstein)}

1856. Gymnodactylus vittatus Lichtenstein, Nomenclator Zool. Berol., p. 6 (type locality, "Laguayra, Puerto-Cabello, and Caracas," Venezuela). 1885. Gonatodes vittatus Boulenger, Cat. Liz. Brit. Mus., vol. 1, p. 60.

The specimens of this species in the collection of the United States National Museum may be listed as follows:

\begin{tabular}{|c|c|c|c|}
\hline No. & Locality & Date & Collector \\
\hline $27819-20$ & San Julian, Venezuela_. & July 19,1900 & M. W. Lyon, jr., and \\
\hline $76809-13$ & Puerto La Cruz, Venezuela & Dec. 4,1928 & J. S. C. Boswell. \\
\hline 4872 & $\begin{array}{l}\text { La Guaira, Venezuela (topo- } \\
\text { type). }\end{array}$ & & 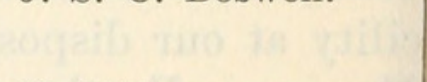 \\
\hline 71051 & $\begin{array}{l}\text { Caracas, Venezuela (topo- } \\
\text { type). }\end{array}$ & & H. Pittier. \\
\hline
\end{tabular}

\section{Genus GYMNODACTYLUS Spix \\ GYMNODACTYLUS HORRIDUS Burmeister}

1861. Gymnodactylus horridus Burmeister, Reise La Plata, vol. 2, p. 522 (type locality, Mendoza, Argentina).-Boulenger, Proc. Zool. Soc. London, 1889, p. 143.

Argentina.-Four specimens, No. 12411 (two examples), collected at Buenos Aires, No. 52597, secured at Mendoza, the type locality. by Dr. Carlos S. Reed, and No. 73502, from Argentina collected by the Breyer brothers. 


\section{Genus HEMIDACTYLUS Oken}

\section{HEMIDACTYLUS MABOUIA (Moreau de Jonnès)}

1818. Gecko mabouia Moreau de Jonnès, Bull. Soc. Philom., Paris, p. 138 (type locality, South America).

1836. Hemidactylus mabouia Duméril and Bibron, Erp. Gén., vol. 3, p. 362.

Brazil.-Six specimens, No. 52612, collected at Bahia on July 27, 1915 , by J. N. Rose, No. 52603, collected at the base of Corcovado on August 4, 1915, by J. N. Rose, No. 52601, secured at Rio de Janiero in July, 1915, by J. N. Rose, No. 71076 , collected at Santos in September, 1925, by W. L. Schmidt, and No. 5679 (2 specimens) from Rio de Janiero taken by the United States Exploring Expedition.

\section{Genus PHYLLODACTYLUS Gray}

\section{PHYLLODACTYLUS ABRUPTESERIATUS Werner}

1912. Phyllodactylus abrupteseriatus Werner, Jahrb. Hamburg Wiss. Anst., Beiheft 2: Mitt. Naturh. Mus. Hamburg, vol. 30, p. 4 (type locality. "wahrscheinlich Brasilien").

This species was described from a specimen which was thought to have come from Brazil, but two examples from Ecuador in the collection of the United States National Museum, No. 14053, secured on December 18, 1884, by Dr. William H. Jones, show the twelve longitudinal rows of enlarged dorsal tubercules, the third and sixth (outer) on each side much shortened, attributed to this form. $P$. abrupteseriatus, like $P$. guayaquilensis, is very closely related to $P$. tuberculosus. All three of these described forms apparently occur in the same general range in Ecuador and possess the same general colorational and scutellational features, except in regard to the arrangement of the dorsal tubercules. Morphologically, abrupteseriatus and guayaquilensis are more closely related than either of these and tuberculosus, for the former lizards possess twelve longitudinal rows of enlarged dorsal tubercules, some of which are shortened, whereas the latter possesses fourteen rows, more of which are fullsized.

\section{PHYLLODACTYLUS BAESSLERI Werner}

1900. Phyllodactylus baessleri Werner, Abhandl. Ber. Zool. Anthropol.-Ethn. Mus. Dresden, vol. 9, no. 2, p. 2 (type locality, Chanchamayo, Peru).

One of these lizards, No. 38569, collected at Las Vocas landing, near Capon, region of Tumbe, Peru, by R. E. Coker, has 12 longitudinal rows of enlarged dorsal tubercules, the lower on each side being much shortened, however. In coloration and general appearance the species closely resembles $P$. tuberculosus and $P$. magister. 
PHYLLODACTYLUS BAURII Garman

1892. Phyllodactylus baurii Garman, Bull. Essex Inst., vol. 24, p. 10 (type locality, Las Cuevas, Charles Island, Galapagos Archipelago).

Charles Island, Galapagos Archipelago.-One specimen, No. 14925, collected on April 8, 1888, by the United States Fish Commission steamer Albatross.

Hood Island, Galapagos Archipelago.-One specimen, No. 15019, collected on April 7, 1888, by the United States Fish Commission steamer Albatross.

\section{PHYLLODACTYLUS GALAPAGOENSIS Peters}

1869. Phyllodactylus galapagoensis Peters, Monatsber. Berlin Akad. Wiss., p. 720 (type locality, Galapagos Islands).

1912. Phyllodactylus galapagoensis daphnensis Van Denburgh, Proc. Calif. Acad. Sci., ser. 4, vol. 1, p. 425 (type locality, Daphne Island, Galapagos Archipelago) .

A topotype of daphnensis from Daphne Island (U.S.N.M. No. 78394, June 23, 1929, G. Pinchot, collector) shows more tubercules on the neck than the single representative of galapagoensis in the American Museum (No. 20524, from Albemarle Island). Since a further comparison of the two individuals reveals no differences that are likely to be constant it becomes necessary to regard daphnensis as a synonym of galapagoensis.

\section{PHYLLODACTYLUS GERRHOPYGUS (Wiegmann)}

1835. Diplodactylus gerrhopygus Wiegmann, Nova Acta Acad. Caes. Leop.Carol., vol. 17 , pt. 1, p. 242 , pl. 18 , fig. 3 (type locality, Chile).

1885. Phyllodactylus gerrhopygus Boulenger, Cat. Liz. Brit. Mus., vol. 1, p. 95.

Peru.-One specimen, No. 38570, obtained on San Gallan Island by R. E. Coker on June 27, 1907.

\section{PHYLLODACTYLUS INAEQUALIS Cope}

1876. Phyllodactylus inaequalis Cope, Journ. Acad. Nat. Sei. Philadelphia, ser. 2, vol. 8 , p. 174, (type locality, Pacasmayo, Peru).

Peru.-One specimen, No. 17542, recorded as having been secured on San Lorenzo Island by Dr. H. E. Ames in 1876. Locality data somewhat doubtful.

\section{PHYLLODACTYLUS LEEI Cope}

1889. Phyllodactylus leei Cope, Proc. U. S. Nat. Mus., vol. 12, p. 145 (type locality, Chatham Island, Galapagos Archipelago).

Chatham Island, Galapagos Archipelago.-One specimen, No. 14957, the type, secured on April 4, 1888, by the United States Fish Commission steamer Albatross. 


\section{PHYLLODACTYLUS MAGISTER Noble}

1924. Phyllodactylus magister NoBLe, Occas. Pap. Boston Soc. Nat. Hist., vol. 5, p. 110 (type locality, Perico, Peru).

This species is very closely related to $P$. tuberculosus.

Peru.-Five paratypes, Nos. 75946-50, collected by G. K. Noble at Bellavista.

\section{PHYLLODACTYLUS MICROPHYLLUS Cope}

1876. Phyllodactylus microphyllus Cope, Journ. Acad. Nat. Sci. Philadelphia, ser. 2, vol. 8, p. 175 (type locality, Valley of Jequetepeque, Peru).

Peru.-Six specimens, No. 75390, taken at Cruz de Hueso, Lima, on May 13, 1928, by R. C. Shannon, Nos. 38571-74, secured at Lobos de Apura on December 3, 1907, by R. E. Coker, and No. 17541, said to be from San Lorenzo Island by Dr. H. E. Ames. The locality data of No. 17541 are uncertain.

\section{PHYLLODACTYLUS PULCHER Gray}

1830. Phyllodactylus pulcher Gray, Spicil. Zool., vol. 1, p. 3, pl. 3, fig. 1 (type locality, tropical America).-Ruthven, Occas. Pap. Mus. Zool. Univ. Michigan, no. 178,1926 , p. 1.

1887. Phyllodactijlus martini Van Lidth De Jeude, Notes Leyden, Mus., vol. 9, p. 130 (type locality, Curaçao).

Curaçao, Dutch Leeward Islands.-One specimen, No. 64172, colJected by T. Gaerste.

\section{PHYLLODACTYLUS TUBERCULOSUS Wiegmann}

1835. Phyllodactylus tuberculosus Wiegmann, Nova Acta Acad. Caes. Leop.Carol., vol. 17 , pt. 1, p. 241 , pl. 18, fig. 2 (type locality, California).

Specimens of this form from the Galapagos Islands and Ecuador, when compared, show much resemblance to each other.

Chatham Island, Galapagos Archipelago.-Two specimens, Nos. 14945 and 14956, collected on April 4, 1888 by the United States Fish Commission steamer Albatross.

Ecuador.-Two specimens, No. 12354, from Guayaquil.

\section{Genus PSEUDOGONATODES Ruthven \\ PSEUDOGONATODES BARBOURI (Noble)}

1921. Lepidoblepharis barbouri NoBle, Ann. New York Acad. Sci., vol. 29, p. 133 (type locality, Perico, Peru).

1926. Pseudogonatodes barbouri PARKER, Ann. Mag. Nat. Hist., ser. 9, vol. 17, p. 298.

Peru.-Seven paratypes, Nos. 75952-54, collected at Bellavista by G. K. Noble, and Nos. 64035-38, secured at Perico by H. G. Raven. 


\section{Genus THECADACTYLUS Oken \\ THECADACTYLUS RAPICAUDUS (Houttuyn)}

1782. Gekko rapicauda Houttuyn, Verh. Zeeuwsch. Genoot. Wet. Vlissingen. vol. 9, p. 323 (type locality, American Islands).

1845. Thecadactylus rapicaudus GraY, Cat. Liz. Brit. Mus., p. 146.-Boulenger, Cat. Liz. Brit. Mus., vol. 1, 1885, p. 3.

The specimens of this species in the collection of the United States National Museum may be listed as follows:

\begin{tabular}{|c|c|c|c|}
\hline No. & Locality & Date & Collector \\
\hline 8296 & South Amerie & & \\
\hline 27790 & La Guaira, Venezuela & July 5,1900 & $\begin{array}{l}\text { M. W. Lyon and W. } \\
\text { Robinson. }\end{array}$ \\
\hline 72759 & Puerto la Cruz, Venezuela_. & & H. Pittier. \\
\hline 13858 & Trinidad $\ldots \ldots$ & Feb. $\quad 2,1884$ & $\begin{array}{l}\text { U. S. Fish Commission } \\
\text { steamer Albatross. }\end{array}$ \\
\hline 5766 & Trinidad & & Thomas. \\
\hline
\end{tabular}

\section{Family IGUANIDAE}

\section{Genus AMBLYRHYNCHUS Bell}

\section{AMBLYRHYNCHUS CRISTATUS Bell}

1825. Amblyrhynchus cristatus BeLL, Zool. Journ., vol. 2, p. 206 (type locality, "Mexico," no doubt in error).

Galapagos Archipelago.-One specimen, No. 37010, from the United States Fish Commission steamer Albatross, taken in 1891. Abingdon Island, Galapagos Archipelago.-One specimen, No. 15002, from the United States Fish Commission steamer Albatross, taken on April 16, 1886.

Daphne Island, Galapagos Archipelago.-One specimen, No. 78393, collected by G. Pinchot on June 23, 1929.

Duncan Island, Galapagos Archipelago.-Six specimens, Nos. 19962-7 from the United States Fish Commission steamer Albatross, taken in 1891.

James Island, Galapagos Archipelago.-One specimen, No. 15187, from the United States Fish Commission steamer Albatross, taken on April 13, 1888.

Tower Island, Galapagos Archipelago.-Three Specimens, No. 65921, collected on May 17, 1923, by J. F. Mitchell, and Nos. 78386-87, taken at Darwin Bay by G. Pinchot on June 16, 1929. 


\section{Genus ANISOLEPIS Boulenger}

This genus is very closely related to Aptycholaemus Boulenger (1891). Relationship between the two genera should be sought through an examination of specimens of Anisolepis grillii and Aptycholaemus longicauda as well as in other ways.

\section{ANISOLEPIS UNDULATUS (Wiegmann)}

1834. Laemanctus undulatus Wiegmann, Herpetologia Mexicana, p. 46 (type locality, Brazil).

1834. Laemanctus obtusirostris Wiegmann, Herpetologia Mexicana, p. 46 (type locality, Brazil).

1843. Laemanctus (Urostrophus) undulatus Fitzinger, Syst. Reptilium, p. 62. 1845. Ecphymotes undulatus Gray, Cat. Liz. Brit. Mus., p. 185.

1845. Ecphymotes obtusirostris Gray, Cat. Liz. Brit. Mus., p. 185.

1885. Enyalius undulatus Boulenger, Cat. Liz. Brit. Mus., vol. 2, p. 121.

1885. Anisolepis iheringii Boulenger, Ann. Mag. Nat. Hist., ser. 5, vol. 16, p. 85 (type locality, San Lorenzo, Rio Grande do Sul, southern Brazil) ; Cat. Liz. Brit. Mus., vol. 2, 1885, p. 122.

1895. Anisolepis bruchi Koslowsky, Revista Mus. La Plata, vol. 6, p. 417 (type locality, Punta Lara, Argentina).

The synonymy of this well marked species is after Werner (1896), p. 471), who has given a synoptic treatment to the genus Anisolepis. It is listed here only to draw further attention to the great change in nomenclature since the appearance of Boulenger's Catalogue in 1885.

Umuguay.-Three specimens, Nos. 65545-47, collected at Paysandu by F. Felippone.

\section{Genus ANOLIS Daudin}

\section{ANOLIS AENEUS Gray}

1840. Anolis aeneus Gray, Ann. Nat. Hist., vol. 5, p. 114 (type locality, unknown).-Ruthven, Occas. Pap. Mus. Zool. Univ. Michigan, no. 143, 1923, p. 6 (Trinidad).

1863. Anolis trinitatis ReinhandT and Lütken, Vidensk. Meddel. Nat. Foren. Kjöbenhavn for 1862, p. 269 (type locality, Trinidad).-Barbour, Mem.

Mus. Comp. Zoöl., vol. 44, no. 2, 1914, p. 281.

1885. Anolis alligator Boulenger, Cat. Liz. Brit. Mus., vol. 2, p. 31, (part).

Tobago.-Thirty-one specimens, Nos. 10102-12, 10114-15, 10117-20 and 10123-36, collected in 1878 by F. A. Ober.

\section{ANOLIS AGASSIZI Stejneger}

1900. Anolis agassizi Stejneger, Bull. Mus. Comp. Zoöl., vol. 36, no. 6, p. 161, pl. 1 (type locality, Malpelo Island, Pacific Ocean, off Colombia).

The collection of the United States National Museum contains the type of this species, No. 22101, and two paratypes, Nos. 22103-104, all collected by Charles H. Townsend, on Malpelo Island on March $5,1891$. 


\section{ANOLIS APOLLINARIS Boulenger}

1919. Anolis apollinaris Boulenger, Proc. Zool. Soc. London, p. 79 (type locality, Bogotá, Colombia).

Ecuador.-Two specimens, Nos. 65493-94, collected at Macas, Province of El Oriente by M. Madira.

\section{ANOLIS CHRYSOLEPIS Duméril and Bibron}

1837. Anolis chrysolepis Duméril and Bibron, Erp. Gén., vol. 4, p. 94 (type locality, Guiana).

Trinidad.-Two specimens, No. 20414, collected by H. Caracciola, and No. 17729, collected by G. T. Wayman in 1891.

Venezuela.-Four specimens, Nos. 22522 and 22524-25 taken on June 23, 1895, and 27818, taken on July 12, 1900, all collected at La Guaira by W. Robinson.

\section{ANOLIS FUSCO-AURATUS D'Orbigny}

1837. Anolis fusco-auratus D'Orbigny, in Duméril and Bibron, Erp. Gén., vol. 4, p. 110 (type locality, Chile).

Brazil.-One specimen, No. 28951, secured at Hyutaihan, Lower Amazonia, by J. B. Steere.

\section{ANOLIS JACARE Boulenger}

1903. Anolis jacare Boulenger, Ann. Mag. Nat. Hist., ser. 7, vol. 11, p. 482 (type locality, Merida, Venezuela).

Colombia.-One specimen, No. 72745, collected at Tapatá, Dept. Norte de Santander, by E. P. Killip in March, 1927.

\section{ANOLIS LATIFRONS Berthold}

1847. Anolis latifrons Berthold, Abhandl. Ges. Göttingen, vol. 3, p. 6 (type locality, Province Popayan, Colombia).

Colombia.-One specimen, No. 4318, secured at Turbo, in the Choco region, by N. Michler.

\section{ANOLIS LINEATUS Daudin}

1802. Anolis lineatus DAUdin, Hist. Nat. Reptiles, vol. 4, p. 66 (type locality, South America).

Curaçao, Dutch Leeward Istands.-One specimen, No. 63240, taken by Thomas Gaerste.

\section{Genus APTYCHOLAEMUS Boulenger}

The lizards of this genus have the general appearance and size of Anisolepis, but they do not have the well developed collar fold of that genus.

\section{APTYCHOLAEMUS LONGICAUDA Boulenger}

1891. Aptycholaemus longicauda Boulenger, Ann. Mag. Nat. Hist., ser. 6, vol. 8, p. 85 (type locality, Riacho del Oro, Argentina).

1895. Anisolepis argentinus KosLowsky, Revista Mus. La Plata, vol. 6, p. 419 (type locality, Province of Buenos Aires, Argentina). 
This lizard is easily distinguished from Anisolepis undulatus by the obsolescence or complete absence of the lateral light band or stripes, as well as by the generic character.

Argentina.-One specimen, No. 73504, collected by the Breyer brothers.

Berg $(1898$, p. 3$)$ is followed here in regarding Anisolepis argentinus Koslowsky (1895) as a synonym of Aptycholaemus longicauda Boulenger (1891).

\section{Genus BASILISCUS Laurenti \\ BASILISCUS BASILISCUS (Linnaeus)}

1758. Lacerta basiliscus Linnaeus, Syst. Nat., ed. 10, vol. 1, p. 206 (type locality, South America).

1768. Basiliscus americanus LAUrenti, Synops. Reptil,, p. 50 (type locality, South America).-Boulenger, Cat. Liz. Brit. Mus., vol. 2, 1885, p. 108. 1926. Basiliscus basiliscus Parker, Ann. Mag. Nat. Hist., ser. 9, vol. 17, p. 550 (Gorgona Island, Gulf of Panama).

Colombia.-Two specimens, No. 32276 from Truando, and No. 4322 from Turbo, both secured by A. Schott. These examples were taken near the Panama-Colombia border.

\section{BASILISCUS GALERITUS Duméril}

1851. Basiliscus galeritus DumériL, Cat. Méth. Rept., p. 61 (type locality, "N.-Grenade," Colombia ).

Ecuador.-One specimen, No. 62786 from Guayaquil, collected by F. W. Goding.

\section{Genus ENYALIOIDES Boulenger}

ENYALIOIDES HETEROLEPIS (Bocourt)

1874. Enyalius heterolepis Bocourt, Ann. Sei. Nat., ser. 5, vol. 19, art. 4, p. 1 (type locality, Veragua, Panama).

1885. Enyalioides heterolepis Boulenger, Cat. Liz. Brit. Mus., vol. 2, p. 114.

Ecuador.-Two specimens, No. 22449, and No. 20612, collected on January 9, 1893, in the Santiago River Valley, both taken by Mark,B. Kerr.

\section{ENYALIOEDS LATICEPS LATICEPS (Guichenot)}

1855. Enyalius laticeps Guichenot, in Castelnau, Exp. l'Amer. du Sud, Zool., Reptiles, p. 20 (type locality, Fonteboa, upper Amazon, Brazil).

Ecuador--One specimen, No. 60521, from San Rafael, Guayas Province, collected by James B. Rorer.

$2609-30-2$ 


\section{ENYALIOIDES MICROLEPIS (O'Shaughnessy)}

1881. Enyalius microlepis O'Shaugnessy, Proc. Zool. Soc. London, p. 238 (type locality, Sarayacu, Ecuador).

1885. Enyalioides microlepis Boulenger, Cat. Liz. Brit. Mus., vol, 2, p. 115

Ecuador.-Two specimens, Nos. 22448 and 22450, collected by Mark B. Kerr.

\section{Genus ENYALIUS Wagler \\ ENYALIUS IHERINGII Boulenger}

1885. Enyalius iheringii Boulenger, Ann. Mag. Nat. Hist., ser. 5, vol. 15, p. 192 (type locality, Rio Grande do Sul, Brazil).

Three specimens, No. 58423 from southern Brazil (Hurter collection), and Nos. 40214-15 from Santa Catherina, taken by W. Ehrdhardt in January, 1910, " from the primeval forests bordering the Rio Humboldt, about 120 kilometers from the sea-coast in the Serra do Mar." Rio Humboldt is an affluent of Rio Itapocu.

\section{Genus IGUANA Gronovius \\ IGUANA IGUANA (Linnaeus)}

1758. Lacerta igvana Linnaeus, Syst. Nat., ed. 10, vol. 1, p. 206 (type locality, America).

1768. Iguana tuberculata LAURenti, Synops. Reptilium, p. 49 (type locality, unknown).-Boulenger, Cat. Liz. Brit. Mus., vol. 2, 1885, p. 189.

1900. Iguana iguana Andersson, Bihang Svenska Vet.-Akad. Handl., vol. 26, sect. 4 , No. 1 , p. 10 .

The specimens of Iguana iguana in the collection of the United States National Museum may be listed as follows:

\begin{tabular}{|c|c|c|c|}
\hline No. & Locality & Date & Collector \\
\hline $\begin{array}{r}28940-43 \\
11413 \\
8542 \\
12628 \\
11314 \\
13869 \\
\\
12202,12265 \\
12295 \\
64597-98 \\
5790 \\
17720 \\
56767 \\
22516 \\
22517 \\
27817 \\
22518 \\
27827-28\end{array}$ & $\begin{array}{l}\text { Lower Amazonia, Brazil } \\
\text { Demerara, British Gui- } \\
\text { ana. } \\
\text { Surinam }\end{array}$ & $\begin{array}{l}\text { Aug. } 20,1891 \\
1906 \\
\text { June } 25,1895 \\
\text { June } 22,1895 \\
\text { July } 10,1900 \\
\text { July } 7,1895\end{array}$ & $\begin{array}{l}\text { Captain Page. } \\
\text { Louis Ruhe. } \\
\text { T. Gill. } \\
\text { Roger Wells, jr. } \\
\text { Hurter Collection. } \\
\text { W. Robinson. } \\
\text { Do. } \\
\text { Do. } \\
\text { Do. } \\
\text { L. Goldschmidt. }\end{array}$ \\
\hline
\end{tabular}




\section{Genus LEIOCEPHALUS Gray}

\section{LEIOCEPHALUS ARENARIUS (Tschudi) ${ }^{2}$}

1845. Steironotus arenarius TscHUd, Fauna Peruana, Herpet., p. 25 (type locality "Huacho, nördlich von Lima", Peru).

1901. Liocephalus rhodogaster Boulenger, Ann. Mag. Nat. Hist., ser. 7, vol. 7, p. 547 (type locality “ Merced, Perené River," central Peru).

1907. Liocephalus arenarius Roux, Revue Suisse Zool., vol. 15, p. 300.

1921. Leiocephalus arenarius Barbour and Noble, Proc. U. S. Nat. Mus., vol, 58 , p. 612 .

1921. Leiocephalus ervingi Barbour and NobLe, Proc. U. S. Nat. Mus., vol. 58, p. 612 (not Stenocercus ervingi Stejneger, 1913).

In describing this lizard as rhodogaster, Boulenger (1901) considered it to be "most nearly related to L. erythrogaster" of Colombia, although the nearest geographical representative of its genetic section of the genus appears to be L. ornatus ornatus of Ecuador. In fact it seems but slightly differentiated from the latter form, having its reduced head plates and small dorsal scutes as well.

Roux (1907) is followed in finding rhodogaster to be synonymous with arenarius, but it is apparent that Barbour and Noble (1921) were not correct in regarding $L$. lineogularis Werner (1901) as another synonym.

Stenocerus ervingi was described from southern Peru by Stejneger (1913), but was later (1921) regarded as Leiocephalus ervingi by Barbour and Noble, who, without examining the type, wrote that "This specimen was only $84 \mathrm{~mm}$. in total length, and the generic characters were difficult or impossible to discern. We have before us a single adult (U.S.N.M. No. 60742), which we believe to be a Leiocephalus, owing to the presence of abdominal ribs and of general Leiocephalus squamation. It is beyond doubt the adult of Stejneger's species." An examination of all of the specimens concerned, including the type of erving $i$ and those younger examples referred to Leiocephalus arenarius by Barbour and Noble, shows Stejneger's species to be correctly diagnosed, and also shows that the Leiocephalus ervingi and the Leiocephalus arenarius of Barbour and Noble are identical.

Peru.-Five specimens, Nos. 60811 taken at Toranton at 8,500 feet elevation on May 1, 1915, and 60705-706, from Chospiyoc on the Huarocondo River taken at 10,000 feet elevation on April 20, 1915, No. 60742 from Machu Picchu on Oct. 30, 1915, at 8,000 feet, and No. 60810 from Ollantaytambo on May 15, 1915, this one secured by O. F. Cook, the first four secured by Edmund Heller, for the Yale-Peruvian Expedition.

\footnotetext{
2 This species should not be confused with "Liocephalus arenarius" Barbour (1916), a form described from Bastion Cay, Turks Islands, W. I., and later renamed Leiocephalus psammodromus Barbour (1920, p. 73).
} 


\section{LEIOCEPHALUS CADUCUS (Cope)}

1862. Scartiscus caducus Cope, Proc. Acad. Nat. Sci. Philadelphia, p. 182 (type locality, Paraguay).-Boulenger, Cat. Liz. Brit. Mus., vol. 2, 1885, p. 127 .

1890. Liocephalus bolivianus Boulenger, Proc. Zool. Soc. London, p. 82 (type locality, Bolivia).-Peracca, Boll. Mus. Zool. Univ. Torino, vol. 12, No. 274,1897 , p. 5 .

1894. Liocephalus caducus Boulenger, Ann. Mag. Nat. Hist., ser. 6, vol. 13, p. 342.

Boulenger (1894) is followed in regarding the genus Scartiscus as identical with Leiocephalus, and also in considering his Liocephalus bolivianus as a synonym of Leiocephatus caducus, the type species of Scartiscus.

An examination of the type of this species (U.S.N.M. No. 5852, collected in Paraguay by Captain Page) shows that the caudals have indistinct verticils of the same general type as those found in Leiocephatus. Posteriorly an indication of a weak lateral crest is present on each side. Still less of an indication of this crest is found in the related form, L. lineogularis, as shown by the examination of the topotype in the collection of the American Museum of Natural History (No. 23154).

Besides the type, the United States National Museum has a topotype from Paraguay, No. 69874, collected in the Chaco by F. Felippone.

\section{LEIOCEPHALUS IRIDESCENS IRIDESCENS (Günther)}

1859. Liocephalus iridescens Günther, Proc. Zool. Soc. London, p. 409 (type locality, Andes of western Ecuador).

Ecuador.-Five specimens, No. 14058, taken on December 18, 1884, by W. H. Jones, Nos. 12275 (2 specimens) and 12281 from Guayaquil. and No. 61755, collected by J. N. Rose at Huigra in 1918.

\section{LEIOCEPHALUS ORNATUS ORNATUS (Gray)}

1845. Leiocephalus ornatus Gray, Cat. Liz. Brit. Mus., p. 219 (type locality, Guayaquil, Tropical America).

Ecuador.-One specimen, No. 33859, from the Alausi Valley, 8,500 feet elevation, secured by S. A. Davis.

\section{LEIOCEPHALUS ORNATUS TRACHYCEPHALUS (Duméril)}

1851. Holotropis trachycephalus A. Dumérrt, Cat. Méth. Coll. Reptiles, Paris, p. 70 (type locality, Nouvelle Grenade, et en par-particulier Santa-Fé de Bogotá).

1885. Liocephalus trachycephalus Boulenger, Cat. Liz. Brit. Mus., vol. 2, p. 169.

Colombia.-One topotype, No. 75958, from Bogotá, collected by Hno. Apolinar Maria in 1920. 


\section{Genus LEIOSAURUS ${ }^{3}$ Duméril et Bibron}

1837. Leiosaurus Duméril and Bibron, Erp. Gén., vol. 4, p. 241 (type species, L. bellii Duméril et Bibron).

1843. Prisidactylus Fitzinger, Syst. Rept., p. 16 (type species, Leiosaurus fasciatus D'Orbigny).

1843. Diplolaemus BeLL, Zool. "Beagle”, Reptiles, p. 19 (type species, D. darwinii Bell).

1845. Ptenodactylus GraY, Cat. Liz. Brit. Mus., p. 224 (type species, Leiosaurus fasciatus D'Orbigny).

The lizards of this genus are in a state of great systematic confusion and a careful study of the species and subspecies is much to be desired. The generic synonymy indicated above, with the exception of the last entry, is after Koslowsky (1896, p. 167).

Aperopristis Peracca, as described, differs little from Leiosaum Duméril and Bibron, the differences exhibited by the type species, $A$. paronae, being slight and seemingly of specific rather than of generic nature. Therefore the two genera may ultimately be considered as one.

\section{LEIOSAURUS BELLII Duméril and Bibron}

1837. Leiosaurus bellii Duméril and Bibron, Erp. Gén., vol. 4, p. 242 (type locality, "Mexique", no doubt in error).

Like Leiosaurus catamarcensis, this species has a row of isolated dark markings along the middorsal line, but it differs, apparently, in having these markings more elongate or pointed before and behind, in possessing slightly smaller dorsal granules, and in the absence of a more or less developed dorsal denticulation. The two forms are obviously very closely related and will probably be found to be subspecifically allied by subsequent workers.

Argentina.-Two specimens from Chubut Province, Patagonia, Nos. 22737-38, received from Museo de la Plata.

\section{LEIOSAURUS BIBRONII (Bell)}

1843. Diplolaemus bibronii BeLL, Zool. “Beagle”, Reptiles, p. 21, pl. 11 (type locality, Port Desire, Patagonia).

1885. Diplolaemus darwinii Boulenger, Cat. Liz. Brit. Mus., vol. 2, p. 126, (part: types) (not of Bell).

Stejneger (1909, pp. 221-223) has indicated that L. bibronii and $L$. darwinii are separable on the character of the scutellation and coloration, the former having larger scales on the head and a different color pattern.

Argentina.-Eight specimens, Nos. 36939-41 and 36944-48, collected in 1898 by J. B. Hatcher in Patagonia, "about margin of small salt lakes."

${ }^{3}$ The generic name "Leiosaurus" Duméril and Bibron was emended by Boulenger (1885, p. 124) to read "Liosaurus." In accordance with article 20 of the International Rules of Zoological Nomenclature the original orthography is retained. 
1898. Liosaurus catamarcensis Koslowsky, Revista Mus. La Plata, vol. 8, p. 169 (type locality, Provincia de Catamarca, Argentina).

1898. Liolaemus catamarcensis Koslowsky, Revista Mús. La Plata, vol. 8, pl. 1, opposite p. 200 (lapsus calami!).

1922. Aperopristis catamarcensis MüLleR, Senckenbergiana, vol. 4, p. 159.

As indicated above, this form is closely related to $L$. bellii. It is also allied to A peropristis paronae (Peracca), the type species of the supposed genus Aperopristis, as pointed out recently by Müller (1922).

Argentina.-Three specimens, No. 63952, collected on November 29, 1920, by Alexander Wetmore at General Roca, Rio Negro, No. 52600 , taken in March, 1914, at Mendoza by Dr. Carlos S. Reed, and No. 63953, secured on December 24, 1920, at Victorica, Pampa, by Alexander Wetmore.

\section{LEIOSAURUS DARWINII (Bell)}

1843. Diplolaemus darvinii BeLt, Zool. "Beagle," Reptiles, p. 20 (type locality, Port Desire, Patagonia).

1898. Liosaurus darwini Koslowski, Revista Mus. La Plata, vol. 8, p. 169.

This species and L. bibronii differ from $L$. bellii and $L$. catamarcensis in not having a distinctly isolated series of dark markings along the middorsal line. The dark markings are either lateral or transverse instead.

Argentina.-Eight specimens, Nos. 22739-40, from Santa Cruz, received from Museo de la Plata; No. 34701 from Neuquén Province, said to be "common on the sands of Cordilleras" collected on November 12, 1903, by J. W. Titcomb, and Nos. 36949-53, taken in 1898 by J. B. Hatcher in Patagonia.

\section{Genus LIOLAEMUS Wiegmann}

\section{LIOLAEMUS BIBRONII (Bell)}

1845. Leiolaemus bibronii BeLL, Zool. "Beagle," Rept., p. 6 (type locality, Port Desire, Argentina).

1845. Leiolaemus bellii Gray, Cat. Liz. Brit. Mus., p. 212 (type locality, Chile). 1845. Leiolaemus lineatus Gray, Cat. Liz. Brit. Mus., p. 213 (type locality, Chile),

Argentina.-Three specimens, No. 73653, Lago Gutierrez, Rio Negro Territory, collected on November 3, 1926, by Dr. and Mrs. R. C. Shannon, No. 34703, collected by J. W. Titcomb on December 5, 1903, and No. 36932, Patagonia, collected by J. B. Hatcher in 1898.

\section{LIOLAEMUS CHILIENSIS (Lesson)}

1831. Calotes chiliensis Lesson, in Duperry, Voy. "Coquille," Zool., vol. 2, pt. 1, p. 36 (type locality, Talachuano, Province de la Concepcion, Chile).

1885. Liolaemus chilensis Boutenger, Cat. Liz. Brit. Mus., vol. 2, p. 141. 
Chile.-Two specimens, No. 15128, taken on February 20, 1888, at Tome by the United States Fish Commission steamer Albatross, and No. 64122, secured in February, 1921, at Valparaiso by Dr. Edwyn P. Reed.

\section{LIOLAEMUS CYANOGASTER (Duméril and Bibron)}

1837. Proctotretus cyanogaster DumérIL and Bibron, Erp. Gén., vol. 4, p. 273 (type locality, Chile).

1885. Liolaenus cyanogaster Boulenger, Cat. Liz. Brit. Mus., vol. 2, p. 145.

Chile.-One specimen, No. 75959, from Cohuelue, southern part, collected by Dr. Thomas Barbour.

\section{LIOLAEMUS DARWINII (Bell)}

1843. Proctotretus darwinii BeLl, Zool. "Beagle," Rept., p. 14 (type locality, Bahia Blanca, northern Patagonia).

1885. Liolaemus darwinii Boulenger, Cat. Liz. Brit. Mus., vol. 2, p. 155.

Argentina.-Four specimens, Nos. 31093-94 from the U. S. Exploring Expedition, No. 38122 from Desaguadero, San Luis Province, collected by Juan Tremoleros, and No. 64131, from Potrerillos, Mendoza, collected by Alexander Wetmore, March 18, 1921.

In some of the above examples a white middorsal line appears, and in others it is obscure or absent.

\section{LIOLAEMUS ELONGATUS Koslowsky}

1896. Liolaemus elongatus Koslowsky, Rev. Mus. La Plata, vol. 7, p. 450 (type locality, Territory of Chubut, Argentina).

Four large representatives of this form, U. S. Nat. Mus. Nos. 63954-7, taken by Alexander Wetmore on December 9, 1920, at Zalapa, Gobernacion de Neuquen, Argentina, indicate that it may be related to $L$. multiformis simonsii. The dorsal scales are very small, much smaller than the lateral and ventral scutes, and distinctly, though not strongly, keeled. Stripes are not present on the body and, with the exception of a more or less pronounced cross-barring on the tail, there is little evidence of a longitudinal arrangement in the dorsal markings. The median dorsal area of the back is unicolor, or nearly so, and dark brown in shade, but the lateral region is light brown or gray with white spots. The flanks and under surfaces are tinged with blue green, and are covered with more or less indistinct slate or brownish flecks.

\section{LIOLAEMUS FITZINGERII (Duméril and Bibron)}

1837. Proctotretus fitzingerii DumérIL and Bibron, Erp. Gén., vol. 4, p. 286 (type locality, Chile).

1885. Liolaemus fitzingeri Boulenger, Cat. Liz. Brit. Mus., vol. 2, p. 150.

Argentina.-Nine specimens, Nos. 36933-38 collected in 1898 by J. B. Hatcher, in Patagonia, No. 38937 from Valle de los Horcones 
collected by Dr. Thomas Barbour, and Nos. 22741 from Catamarca and 22762 from Chubut, the last two received from Museo de la Plata.

\section{LIOLAEMUS HATCHERI Stejneger}

1909. Liolaemus hatcheri SteJ Neger, Rep. Princeton Univ. Exp. Patagonia, vol. 3, pt. 2, p. 218 (type locality, southern Patagonia, Territory of Santa Cruz).

Argentina.-Six specimens, No. 36912, the type, and Nos. 36907-11, paratypes, collected by J. B. Hatcher in Patagonia in 1898.

\section{LIOLAEMUS KINGII (BelI)}

1843. Proctotretus kingii BeLL, Zool. "Beagle," Reptiles, p. 13, (type locality, Port Desire in Patagonia).

1885. Liolaemus kingii Boulenger, Cat. Liz. Brit. Mus., vol. 2, p. 149.

Argentina.-Twenty specimens from Patagonia, No. 34702, taken by J. W. Titcomb at 1,000 feet elevation in the Mountains of Neuquen on November 10, 1903, and Nos. 36913-31, secured by J. B. Hatcher in 1898 .

\section{LIOLAEMUS LEMNISCATUS Gravenhorst}

1838. Liolaemus lemniscatus Gravenhorst, Nova Acta Caes. Acad. Leop.-Carol., vol. 18, pt. 2, p. 731 (type locality, Valparaiso).-Boulenger, Cat. Liz. Brit. Mus., vol. 2, 1885, p. 143.

1845. Liolaemus elegans Tschudi, Fauna Peruana, Herpet., p. 33 (type locality, Chancay, Peru).

1885. Liolaemus fuscus Boulenger, Cat. Liz. Brit. Mus., vol. 2, p. 144 (type locality, Valparaiso, Chile).

Roux (1907, p. 297) has compared the types of Liolaemus elegans Tschudi with examples of $L$. lemniscatus and has considered them to be identical.

South America.-Two specimens, Nos. 11466 and 9822.

Chile.-Five specimens, No. 62257, obtained at Calama by C. G. Abbott, and No. 5525 (four specimens) taken at Santiago by Lieut. J. M. Gilliss.

Peru.-One specimen, No. 52211, from Oroya, collected in the high Andes at 12,000 feet elevation, by J. N. Rose. This example, having about 50 scale rows around the body, is typical of the Liolaemus fuscus of Boulenger (1885), and apparently of Liolaemus elegans Tschudi (1845) as well.

\section{LIOLAEMUS LINEOMACULATUS Boulenger}

1885. Liolaemus lineomaculatus Boulenger, Cat. Liz. Brit. Mus., vol. 2, p. 149 (type locality, Patagonia).

Argentina.-Seventeen specimens, No. 22765 from Chubut, Nos. 52963-64 from Mendoza, collected in 1914 by R. Sanzin, and Nos. 
36893-905 from Patagonia and 36906 from "The Salinas," near mouth of Rio Santa Cruz, the latter series collected by J. B. Hatcher in 1898 .

\section{LIOLAEMUS MULTIFORMIS MULTIFORMIS (Cope)}

1876. Proctotretus multiformis Cope, Journ. Acad. Nat. Sci. Philadelphia, p. 173 (type locality, Lake of Titicaca, Peru).

1885. Liolaemus multiformis Boulenger, Cat. Liz. Brit. Mus., vol. 2, p. 153.

1901. Liolaemus annectens Boulenger, Ann. Mag. Nat. Hist., ser. 7, vol. 7, p. 546 (type locality, "Cayllome and Sumbay," Andes of Peru).Stejneger, Proc. U. S. Nat. Mus., vol. 45, 1913, p. 546.

Peru.-Six specimens, No. 75960, taken at Vincocayo at 14,500 feet elevation by Samuel Garman, and Nos. 49544 -48, collected between Cotahuasi and Chuquibamba at 15,500 feet elevation by the YalePeruvian Expedition.

\section{LIOLAEMUS NIGROMACULATUS (Wiegmann)}

1834. Tropidurus nigromaculatus Wiegmann, in Meyen, Reise um die Erde 1830-1832), vol. 1, p. 206 (nomen nudem); Nova Acta Acad. Caes. Leop.-Carol., vol. 17, 1835, pt. 1, p. 229 (type locality, Chile).

1845. Leiolaemus nigromaculatus GraY, Cat. Liz. Brit. Mus., p. 213.

Chile.-Three specimens, No. 5692, secured at Valparaiso by members of the United States exploring expedition, and Nos. 38934-35, taken at Caldera by Thomas Barbour.

Peru.-One specimen, No. 12199, collected by C. H. Raymond.

\section{LIOLAEMUS NITIDUS (Wiegmann)}

1834. Tropidurus nitidus Wifgmann, in Meyen, Reise um die Erde (1830-1832), vol. 1, p. 206 (nomen nudem) ; Nova Acta Acad. Caes. Leop.-Carol., vol. 17, 1835, pt. 1, 234 (type locality, Chile).

1885. Liolaemus nitidus Boulenger, Cat. Liz. Brit. Mus., vol. 2, p. 140.

Chile.-Three specimens, No. 5869, obtained at Valparaiso by the United States exploring expedition, and Nos. 64123-24, collected at Valparaiso by Dr. Edwyn P. Reed in February, 1921.

\section{LIOLAEMUS PICTUS PICTUS (Duméril and Bibron)}

1837. Proctotretus pictus DumérIL and BiBßon, Erp. Gén., vol. 4, p. 276 (type locality, Chile).

1885. Liolaemus pictus Boulenger, Cat. Liz. Brit. Mus., vol. 2, p. 151.

Argentina.-One specimen, No. 73654, collected by Dr. and Mrs. R. C. Shannon on November 3, 1926, at Lago Gutierrez, Rio Negro Territory.

Chile.-One specimen, No. 58398, from the Hurter Collection. $2609-30-3$ 


\section{LIOLAEMUS TENUIS (Duméril and Bibron)}

1837. Proctotretus tenuis, Duméril and Bibron, Erp. Gén., vol. 4, p. 279 (type locality, Chile).

1885. Liolaemus temuis Boulenger, Cat. Liz. Brit. Mus., vol. 2, p. 152.

Chile.-Twenty specimens, No. 15127, secured at Lota on February 17,1888 , by members of the United States Fish Commission Steamer Albatross, No. 5518 (18 specimens) taken at Santiago by Lieut. J. M. Gilliss, and No. 5652, from Valparaiso, collected on the United States exploring expedition to the Southern Hemisphere.

\section{LIOLAEMUS WIEGMANNII (Duméril and Bibron)}

1837. Proctotretus wiegmannii DumérIL and Bibron, Erp. Gén., vol. 4, p. 284 (type locality, Chile).

1885. Liolaemus wiegmanni Boulenger, Cat. Liz. Brit. Mus., vol, 2, p. 156.

Argentina.-Four specimens, No. 52596, collected at Mendoza by Dr. Carlos S. Reed, and Nos. 63948-50, taken at Victorica, Pampa, by Alexander Wetmore during the month of December, 1920.

Paraguay.-One specimen, No. 12197, collected by Captain Page. Uruguay.-Twenty-three specimens, Nos. 48609, 70477-81, and 73531-32, collected by F. Felippone, Nos. 65561, and 65564-65, secured by F. Felippone at Buceo, Montevideo, No. 65616, taken at Cape Polonia on December 6, 1922, by H. M. Smith, No. 65556, obtained at Carrasco in March, 1916, by F. Felippone, No. 65540, collected at Canelones by F. Felippone, Nos. 68037-38, collected at Malvin, Montevideo, by F. Felippone, Nos. 65566-74 and 73916, from Montevideo, collected by F. Felippone, and No. 38111, from Punta Carretas, near Montevideo, collected by J. Tremoleras on November 17, 1907.

Seven specimens with doubtful locality data are Nos. 17543-49, supposedly from San Lorenzo Island, Peru, collected by Dr. H. E. Ames.

\section{Genus NOROPS Wagler \\ NOROPS AURATUS (Daudin)}

1803. Anolis auratus Daudin, Hist. Nat. Reptiles, vol. 4, p. 89 (type locality, not indicated).

1845. Norops auratus Gray, Cat. Liz. Brit. Mus., p. 207.

Dutch Guiana.-One specimen, No. 13818, from Paramaribo, collected by C. J. Hering on March 18, 1884.

\section{Genus PLICA Gray}

SYNOPSIS OF THE SPECIES

1. Occipital plate about one-fourth as wide as the breadth of the head; a spiny, pouch-like projection present in the region a little posterior to the upper border of the tympanum. 
Occipital plate at least one-half as wide as the breadth of the head; no spiny, pouch-like projection in the region a little posterior to the upper border of the tympanum.

2. Posterior tibial scales without prominent projecting spines; supraocular scales wider, band-like; caudal crest usually composed of low denticulations P. plica (Linnaeus).

(Northern South America.)

Posterior tibial scales with prominent projecting spines; supraocular scales squarish or rounded, not band-like; caudal crest composed of a series of thin, moderately elevated serrations

P. stejnegeri, new species.

(Argentina.)

3. Occipital plate large, about half as wide as the head___P. umbra (Linnaeus). (Northern South America.)

Occipital plate very large, "much broader than half the breadth of the head"

P. tuberculatum Andersson.

(Bolivia.)

\section{PLICA PLICA (Linnaeus)}

1758. Lacerta plica Linnaeus, Syst. Nat., ed. 10, vol. 1, p. 208 (type locality, "in Indiis").

1885. Uraniscodon plica Boulenger, Cat. Liz. Brit. Mus., vol. 2, p. 180.

1901. Plica plica SteJneger, Proc. U. S. Nat. Mus., vol. 24, p. 182.

Dutch Guiana.-One specimen, No. 11047, collected by C. J. Hering in Surinam.

Trinidad.-Two specimens, Nos. 17727-28, collected by G. T. Wayman in 1891.

Venezuela.-Two specimens, Nos. 27798-99, taken at La Guaira by M. W. Lyon and W. Robinson.

PLICA STEJNEGERI, new species

Diagnosis.-Head scales mostly small; supraoculars not band-like; occipital plate large, about one-fourth as broad as the breadth of the head; dorsal and caudal crest moderate, prominent, composed of thin serrations; dorsal and caudal scales imbricate and strongly keeled; posterior tribial scales strongly spinose; two complete and one incomplete gular folds; legs short and heavy. Dorsal ground color gray with brown spots and reticulations, the latter tending to form a series of obtuse chevrons on the back; throat and upper chest marbled with grayish but not black.

\section{Habitat.-Argentina.}

Type specimen.-U.S.N.M. Cat. No. 73505; Argentina; Breyer Bros., collectors.

Description of type specimen.-Head moderate, snout short; nostril latero-superior, separated from rostral; superciliary edge projecting, angular; upper head scales smooth or tubercular, but not distinctly keeled; two series of interorbitals; three to five enlarged supraoculars, these more or less squarish or rounded and not occupying over half of the supraocular region; parietals indistinct or 
juxtaposed between the supraocular area and the occipital plate; occipital large, about one-fourth as broad as the breadth of the head; anterior border of tympanum with long projecting spines.

Neck only slightly constricted, strongly plicate and pouched inferiorly; two complete and one incomplete gular folds, the latter's halves distinct and continuous with a dorso-lateral fold on each side, but failing to meet medially; sides of neck with many tufts of small, erect, spinose scales.

Dorsal scales slightly larger than lateral scales; both dorsal and lateral scales moderate, strongly keeled, with sharp projecting posterior spines; dorsal crest moderate, serrations thin; dorso-lateral fold covered with many small, erect, spinose scales; a second more or less distinct fold on each side from axilla to groin; ventral scales about the same size as the largest dorsals but smaller than all of the anterior caudals, smooth; limbs covered by large, keeled, imbricate scales; infradigital lamellae distinctly keeled.

The adpressed hind limb does not reach beyond the tympanum.

Tail thick at its base, a little compressed, and with a moderate dorsal crest.

Grayish olive or greenish above, spotted and marbled with dark brown; the brown reticulations forming more or less distinct cross. bands on the back, tail and limbs; a collar of blackish or slaty hue; throat and upper chest shaded or reticulated with gray; other lower surfaces yellowish.

Dimensions (in millimeters).-Tip of snout to anus, 120; tip of snout to second gular fold, 35; tip of snout to anterior border of tympanum, 28 ; tip of snout to center of eye, 17 ; tip of snout to posterior border of occipital plate, 24; width of head, 23; length of front leg, 53; length of hind leg, 75 ; length from base of fifth hind toe to tip of fourth toe, 27.

Remarks.-This species is easily distinguished from umbra and tuberculatum by the characters used in the synopsis of the species presented above. Its closest reiative is plica with which it may be best compared as follows:

\begin{tabular}{|c|c|c|}
\hline Character & P. stejnegeri & P. plica \\
\hline $\begin{array}{l}\text { Supraoculars } \\
\text { Dorsal crest } \\
\text { Serrations of dorsal crest } \\
\text { Size of dorsal scales. } \\
\text { Posterior tibials } \\
\text { Legs. }\end{array}$ & $\begin{array}{l}\text { Smaller, not band-like... } \\
\text { Moderate... } \\
\text { Thin } \\
\text { Moderate.... } \\
\text { Strongly spinose.... } \\
\text { Short and heavy }\end{array}$ & $\begin{array}{l}\text { Larger, bandlike. } \\
\text { Low. } \\
\text { Usually much thicker. } \\
\text { Small. } \\
\text { Not spinose. } \\
\text { Longer and more } \\
\text { slender. }\end{array}$ \\
\hline
\end{tabular}

The tail of the type specimen is broken.

This species is named for Dr. Leonhard Stejneger. 


\section{Genus POLYCHRUS Cuvier}

\section{POLYCHRUS ACUTIROSTRIS Spix}

1825. Polychrus acutirostris SpIx, Spec. Nov. Lacert. Brasil., p. 15 (type locality, Bahia, Brazil).

Paraguay.-Three specimens, No. 58619 from the Hurter collection, and Nos. 4937 and 12182, collected by Captain Page.

\section{POLYCHRUS FEMORALIS Werner}

1910. Polychrus femoralis Werner, Mitt. Naturhist. Mus. Hamburg, Jahrb. Hamburg, Wiss. Anst., vol. 27, beiheft 2, p. 21 (type locality, Guayaquil, Ecuador).

Ecuador.-One specimen, No. 12271, a topotype from Guayaquil, which agrees well with the characters set forth in the original description. The ventral scales are unicarinate as in marmoratus.

\section{POLYCHRUS MARMORATUS (Linnaeus)}

1758. Lacerta maimorata LinNaeus, Syst. Nat., ed. 10, vol. 1, p. 208 (type locality, America).

1820. Polychrus marmoratus Merrem, Syst. Amphib., p. 48.

Brazil.-Two specimens, No. 6011 from the Amazon Basin collected by Lieutenant Herndon, and No. 58430 from S. Leopoldina, the latter from the Hurter collection.

Surinam.-One specimen, No. 11044, collected by C. J. Hering in May, 1881.

Trinidad.-Three specimens, No. 5791, collected by T. Gill, and Nos. 17725-26, taken at Port of Spain, by Mr. Roger Welles on August 25, 1891.

Venezuela.-Five specimens, No. 27783 from Macuto collected by M. W. Lyon, jr., Nos. 22520-21, secured on Margarita Island on July 14, 1895, by W. Robinson, and Nos. 27784-85 from Cururuti at 3,000 feet elevation on July 7, 1900, by M. W. Lyon, jr.

\section{Genus PROCTOTRETUS Duméril and Bibron}

1837. Proctotretus Duméril and Bibron, Erp. Gén., vol. 4, p. 266 (type species, $P$. pectinatus Duméril et Bibron).

1857. Saccodeira Girand, Proc. Acad. Nat. Sci. Philadelphia, p. 197 (type species, S. ornatissima Girard).

\section{PROCTOTRETUS AZUREUS (Müller)}

1882. Tropidocephalus azureus MüLler, Verh. Nat. Ges. Basel, vol. 7, pp. 160161 (type locality, Uruguay).

1885. Saccodeira azurea Boulenger, Cat. Liz. Brit. Mus., vol. 2, p. 160.

Uruguay.-One topotype, No. 65535, from Cerro Largo, collected by F. Felippone. 
PROCTOTRETUS ORNATISSIMUS (Girard)

1857. Saccodeira ornatissima Girand, Proc. Acad. Nat. Sci. Philadelphia, p. 198 (type locality, lower cordilleras, just below Obrajillo, and Yanga, Peru).

In the young of this species the black dorsal markings, instead of being more or less irregular and indistinct as in the adult, are regularly arranged, forming paired, light edged triangles on each side of the dorsal crest. Also, the lower surfaces are lighter, with only a few dark markings on the throat, instead of deeply suffused with bluish as in the adult, and apparently the young have smooth head scales or feebly keeled ones.

Peru.-Two specimens, No. 5655, a co-type from Yanga, collected by the United States exploring expedition, and No. 75398, taken at Verrugas, Lima, by R. C. Shannon on July 8, 1928.

\section{PROCTOTRETUS PECTINATUS Duméril and Bibron}

1837. Proctotretus pectinatus Duméril and Bibron, Erp. Gén., vol. 4, p. 292 (type locality, Chile).

Argentina.-One specimen, No. 22736 from Bahia-Blanca received from Museo de la Plata.

\section{Genus STENOCERCUS Duméril and Bibron}

\section{STENOCERCUS BOETTGERI Boulenger}

1911. Stenocercus boettgeri Boulenger, Ann. Mag. Nat. Hist., ser. 8, vol. 7, p. 22 (type locality, Huancabamba, Peru).

Ecuador.-One specimen, No. 61756, collected in 1918 at Loja by J. N. Rose. This example is described as a "green lizard" on the field tag. The preserved specimen is dull, uniform, greenish black, without additional markings. The gular fold is well developed, the throat bluish black, and the other under parts white to grayish.

\section{STENOCERCUS CRASSICAUDATUS (Tschudi)}

1845. Scelotrema crassicaudatum Tschudi, Fauna Peruana, Herpet., p. 28 (type locality, Urubamba, Peru).

1885. Stenocercus torquatus Boulenger, Cat. Liz. Brit. Mus., vol. 2, p. 133, pl. 8, fig. 1 (type locality, Peru).

1913. Stenocercus ervingi SteJneger, Proc. U. S. Nat. Mus., vol. 45, p. 545 (type locality, Huadquinia, Peru).

Peru.-Nine specimens, Nos. 60731-32 taken on September 10, 1915, from the Cosireni River Valley, No. 49550, the type of Stenocercus ervingi, from Huadquinia, Nos. $60710-13$ and 60736 taken October 15, 1915, at San Fernando on the Rio Cosireni, 4,500 feet elevation, and No. 60725 from Santa Ana at 3,400 feet taken in October, 1915, all collected by members of the Yale-Peruvian Expedition. 


\section{Genus TROPIDURUS Wied}

The nomenclature of Van Denburgh and Slevin (1913) is followed in dealing with the Tropiduri of the Galapagos Islands.

\section{TROPIDURUS ALBEMARLENSIS ALBEMARLENSIS (Baur)}

1890. Tropidurus albemarlensis BAUR, Biol. Centralbl., vol. 10, p. 478 (nomen nudem) ; Festschrift für Leuckart, 1892, pp. 265, 269 (type locality, Tagus Cove, Albemarle Island, Galapagos Archipelago).-VAN DenBURgh and Slevin, Proc. Calif. Acad. Sci., ser. 4, vol. 2, 1913, p. 172.

1890. Tropidurus indefatigabilis BAuR, Biol. Centralbl., vol. 10, p. 478 (nomen nudem) ; Festschrift für Leuckart, 1892, pp. 265, 268 (type locality, Indefatigable Island, Galapagos Archipelago).

1892. Tropidurus jacobii BAur, Festschrift für Leuckart, p. 269 (type locality, James Island, Galapagos Archipelago).

This form occurs on a number of the Galapagos Islands. The United States National Museum has specimens from four of these:

Albemarle.-Twelve specimens Nos. 15003-11 and 15013, cotypes, secured on April 10, 1886, by the United States Fish Commission steamer Albatross, and Nos. 58616-7, from the Hurter collection.

Daphne.-Six specimens, Nos. 78395-400, collected by G. Pinchot on June 23, 1929.

Indefatigable.-Sixteen specimens, Nos. 14931-7 and 14939-40, cotypes of $T$. indefatigabilis Baur, secured on April 12, 1888, by the United States Fish Commission steamer Albatross, Nos. 78388-92 collected on June 23, 1929, by G. Pinchot, and Nos. 58310-1 secured August 8, 1906, from the Hurter Collection.

James.-Twenty-seven specimens, Nos. 14897-14915, and 14917-24, cotypes of T. jacobii Baur, secured on April 12, 1888, by the United States Fish Commission steamer Albatross.

\section{TROPIDURUS ALBEMARLENSIS BARRINGTONENSIS (BaUr)}

1892. Tropidurus barringtonensis BAUR, Festschrift für Leuckart, p. 268 (type locality, Barrington Island, Galapagos Archipelago).

1913. Tropidurus albemarlensis barringtonensis VAN Denburgh and Slevin, Proc. Calif. Acad. Sci., ser. 4, vol. 2, p. 168.

Barrington Island, Galapagos Archipelago.-Two topotypes, Nos. 58686-87, from the Hurter collection, collected July 10, 1906.

\section{TROPIDURUS BIVITTATUS (Peters)}

1871. Craniopeltis bivittata Peters, Monatsber. Berlin Akad. Wiss., p. 645 (type locality, Chatham Island, Galapagos Archipelago).

1889. Tropidurus lemniscatus Cope, Proc. U. S. Nat. Mus., vol. 12, p. 145 (type locality, Chatham Island, Galapagos Archipelago).

1913. Tropidurus bivittatus Van Denburgh and Slevin, Proc. Calif. Acad. Sci., ser. 4, vol. 2, p. 155.

Chatham Island, Galapagos Archipelago.-Nineteen specimens, Nos. 22125, taken March 29, 1891; 14946-55 and 14959-64, taken 
April 4, 1888, from the United States Fish Commission steamer Albatross; and Nos. 58308-309, collected on January 25, 1906, from the Hurter collection; Nos. 14946-55 and 19459-64 are cotypes of Tropidurus lemniscatus Cope. All these are topotypes of bivittatus.

\section{TROPIDURUS DELANONIS Baur}

1890. Tropidurus delanonis BAUR, Biol. Centralbl., vol. 10, p. 478 (type locality, Hood Island, Galapagos Archipelago).-VAN Denburgh and Slevin, Proc. Calif. Acad. Sci., ser. 4, vol. 2, 1913, p. 159.

1890. Tropidurus hoodensis Baur, Biol. Centralbl., vol. 10, p. 478 (type locality, Hood Island, Galapagos Archipelago).

Gardners Istand, Galapagos Archipelago.-Five specimens, Nos. 14926-30.

Hood Island, Galapagos Archipelago.-Twenty-one specimens, Nos. 15014-18 and 15020-25, taken on April 7, 1888, cotypes of Tropidurus delanonis and T. hoodensis Baur, secured from the United States Fish Commission steamer Albatross, Nos. 78401-408, collected in July, 1929, by G. Pinchot, and Nos. 58614-15 taken June 25, 1906, from the Hurter collection.

As noted by Van Denburgh and Slevin (1913) Tropidurus hoodensis is a substitute name for $T$. delanonis, having appeared as such in the reprint of the issue of the Biologische Centralblatt cited above. Since there was no preoccupation, the oldest name, delanonis, has been applied to the species. From the nature of the case, it is evident that the cotypes are the same for both "species."

\section{TROPIDURUS DUNCANENSIS Baur}

1890. Tropidurus duncanensis BAUR, Biol. Centralbl., vol. 10, p. 479 (type locality, Duncan Island, Galapagos Archipelago).-VAN Denburgh and Slevin, Proc. Calif. Acad. Sci., ser. 4, vol. 2, 1913, p. 147.

Duncan Istand, Galapagos Archipelago.-Twenty-two specimens, Nos. 14941-44, taken A pril 13, 1888, cotypes, and 22109-24, topotypes, both sets secured on April 2, 1891, by the United States Fish Commission steamer Albatross, and Nos. 56890-91, from the Hurter collection, taken in December, 1905.

\section{TROPIDURUS HABELII (Steindachner)}

1876. Tropidurus pacificus habelii STEINDACHNER, Festschrift Zool.-Bot. Ges. Wien, p. 314, pl. 2, fig. 2 (type locality, Indefatigable [?], and Bindloe Islands, Galapagos Archipelago).

Bindloe Istand, Galapagos Archipelago.-Two specimens, Nos. 58484-85, from the Hurter collection, taken on September 17, 1906. 
TROPIDURUS OCCIPITALIS BOCOURTI (Boulenger)

1874. Aneuporus occipitalis Bocourt, Miss. Sci. Mexique Amer. Centr., p. 215, pl. 18, fig. 1 (type locality, Peru).

1885. Tropidurus bocourtii Boulenger, Cat. Liz. Brit. Mus., vol. 2, p. 173, [new name for Tropidurus occipitalis (Bocourt, 1874), preoccupied by Tropidurus occipitalis (Peters, 1871)].

Peru.-Three specimens, Nos. 75962-64, collected at Bellavista by G. K. Noble.

\section{TROPIDURUS OCCIPITALIS OCCIPITALIS (Peters)}

1872. Tropidurus (Laemopristus) occipitalis PETERs, Monatsber. Berlin Akad. Wiss. (1871), p. 645 (type locality, Peru).

Ecuador.-One specimen, No. 75965, Posorja, Gulf of Guayaquil, collected by G. Baur.

TROPIDURUS PACIFICUS Steindachner

1876. Tropidurus (Craniopeltis) pacificus STEIndacener, Festschrift Zool.-Bot. Ges. Wien, p. 313, pl. 2, fig. 3 (type locality, Indefatigable ? and Blindloe Islands, Galapagos Archipelago).

1890. Tropidurus abingdonii BaUR, Biol. Centralbl., vol. 10, p. 479 (type locality,

Abingdon Island, Galapagos).

Abingdon Island, Galapagos Archipelago.-Thirty-seven specimens, Nos. 14966-98 and 15001, co-types of T. abingdonii Baur, and the type No. 14965, both lots secured on April 16, 1888, by the United States Fish Commission steamer Albatross, and Nos. 58387-88 from the Hurter collection, taken September 22, 1906.

\section{TROPIDURUS PERUVIANUS (Lesson)}

1826. Stellio peruvianus Lesson, in DuperRy, Voy. "Coquille," Zool. Atlas, Reptiles, pl. 2, fig. 2 (photograph) ; Voy. "Coquille," Zool. Text, vol. 2, pt. 1, 1831, p. 40 (type locality, "Par la mer au pied de Callao, et sur la côte nue et dessechée de Payta," western coast of Peru).

1885. Tropidurus peruvianus Boulenger, Cat. Liz. Brit. Mus., vol. 2, p. 174. 1900. Tropidurus thomasi Boulenger, Ann. Mag. Nat. Hist., ser. 7, vol. 6, p. 184 (type locality, Eten, coast of Peru).

1901. Tropidurus theresiae Steindachner, Anz. Akad. Wiss. Wien, vol. 38, p. 195 (type locality, Ancon, near Lima, Peru).

The specimens listed on page 26 have been carefully compared, and, on the basis of their variations, it is impossible to recognize Tropidurus thomasi Boulenger (1900) as a distinct taxonomic unit. In addition, a topotype of $T$. theresiae Steindachner (1901, U.S.N.M. No. 13980 , shows it to be likewise synonymous with the present species. 
The collection of Tropidurus perwianus in the United States National Museum may be listed as follows:

\begin{tabular}{|c|c|c|c|}
\hline No. & Locality & Date & Collector \\
\hline & 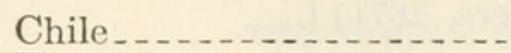 & & urter collecti \\
\hline & & Dec. 18,1884 & H. Jones. \\
\hline $\begin{array}{r}5715,5672 \\
5704\end{array}$ & & & $\begin{array}{l}\text { United States Ex- } \\
\text { ploration Expedi- }\end{array}$ \\
\hline 17538 & Peru, San Lorenzo Id. &,-- 1876 & H. E. Ames. \\
\hline & $\begin{array}{l}\text { Ancon, Peru (topotype of } \\
\text { theresiae). }\end{array}$ & Oct. $\quad 4,1884$ & George Keifer. \\
\hline 68735 & $\begin{array}{c}\text { Coast near Callao, Peru } \\
\text { (topotype). }\end{array}$ & Jan. 14,1884 & W. H. Jones. \\
\hline 75 & Chosica, Lima, Peru.. & June 16,1928 & R. C \\
\hline & $\begin{array}{l}\text { Chosica Canyon, Lima, } \\
\text { Peru. }\end{array}$ & & send. \\
\hline 75391 & $\begin{array}{l}\text { Cruz de Hueso, Lima, } \\
\text { Peru. }\end{array}$ & May 13,1928 & R.C. Shannon. \\
\hline & Lima (city), Peru & & Ale: \\
\hline & Tier & Dec. 1 & \\
\hline & ndo, $\mathrm{Pe}$ & Sept. 2 & W. H. \\
\hline 2056 & $\begin{array}{l}\text { North Chincha Island, } \\
\text { Peru. }\end{array}$ & June 11, & R. E. Coker. \\
\hline 7336 & Paita, Peru (topotypes) & - & W. L. \\
\hline & & Aug. 5, & J. N. R \\
\hline 5151 & Rio Rimac Valley, Peru 1 & Apr. $\quad 8,1914$ & C. H. T. Townsend. \\
\hline & Da & May 20,1928 & R. C. Shann \\
\hline & is Canyo & Apr. 8, & C. H. T. T \\
\hline 75394-97 & Verrugas Canyon, Peru & June 25,1928 & R. C. Shannon. \\
\hline
\end{tabular}

1 Half way between Verrugas and San Bartolome, altitude 5,250 feet.

\section{TROPIDURUS SPINULOSUS (Cope)}

1862. Microlophus spinulosus Cope, Proc. Acad. Nat. Sci. Philadelphia, p. 351 (type locality, Paraguay).

Paraguay.-Three specimens, No. 5956, the holotype, and No. 4904, both collected by Lieutenant Page, and No. 58848, from the Hurter collection.

\section{TROPIDURUS TORQUATUS HISPIDUS (Spix)}

1825. Agama hispida SpIx, Spec. Nov. Lacert. Brasil, p. 12, pl. 15, fig. 2 (type locality, Bahia, Brazil).

South America.-One specimen, No. 36368.

Brazil.-Three specimens, No. 9324 (a topotype), collected at Bahia on July 12, 1874, by J. Russell, No. 52611, collected at Toca de Onça, Bahia by J. N. Rose on June 27, 1915, and No. 58386, taken at Pernambuco in December, 1895, from the Hurter collection. 
1820. Stellio torquatus WIED, Reise nach Brasilien (1815-1817), vol, 1, p. 106 (type locality, Brazil).

Argentina.-Two specimens, No. 73503; No. 52962 from Missiones. Brazil.-Sixteen specimens, Nos. 5668 and 5877 from Rio de Janeiro collected by the United States exploring expedition, and Nos. 15107-19, secured on Abrolhos Island on December 27, 1887 by the United States Fish Commission steamer Albatross.

Paraguay.-Two specimens, No. 5857, collected by Captain Page. South America.-One specimen, No. 5669, reecived from S. F. Baird.

\section{Family ANGUIDAE}

\section{Genus DIPLOGLOSSUS Wiegmann}

\section{DIPLOGLOSSUS MONOTROPIS (Kuhl)}

1820. Scincus monotropis KUHL, Beitr. Zool. Vergl. Anat., p. 128 (type locality, unknown).

1834. Diploglossus monotropis Wibgmann, Herpetologia Mexicana, p. 36.

Colombia.-One specimen, No. 73302, collected in the Choco near the San Juan River by E. J. Paripana.

Ecuador.-One specimen, No. 20609, collected by M. B. Kerr at Plaza de Oro on the Santiago River on February 14, 1893, at 200 feet elevation.

South America.-One specimen, No. 22451, also from M. B. Kerr.

\section{Genus OPHIODES Wagler}

\section{OPHIODES STRIATUS (Spix)}

1825. Pygopus striatus SPIx, Spec. Nov. Lacert. Brasil, p. 25 (type locality, Rio de Janeiro, Brazil).

1885. Ophiodes striatus Boulenger, Cat. Liz. Brit. Mus., vol. 2, p. 296.

A careful comparison of specimens from both north and south of the type locality of grilli, described by Boulenger (1913) from Parana, Brazil, indicates that it is probably merely a variation of the present species. The most remarkable character attributed to grilli, the contact of the azygous prefrontal with the second supraocular, is shown by none of the specimens listed below, although the approach of these two plates is more pronounced in some examples than in others. 
The specimens of striatus in the collection of the United States National Museum may be listed as follows:

\begin{tabular}{|c|c|c|}
\hline No. & Locality & Collector \\
\hline 9820 & South America & United States Navy. \\
\hline $73515-21$ & Argentina & Breyer Brothers. \\
\hline 5710 & Rio de Janeiro, Brazil (topotype) & $\begin{array}{l}\text { United States Ex- } \\
\text { ploration Expedi- } \\
\text { tion. }\end{array}$ \\
\hline 56998 & Santa Catharina, Brazil, 1896 & Hurter collection. \\
\hline $\begin{array}{r}76366-7 \\
5849\end{array}$ & $\begin{array}{l}\text { São Paulo, Brazil } \ldots \ldots \\
\text { Paraguay }\end{array}$ & $\begin{array}{l}\text { Instituto Butantan. } \\
\text { Captain Page. }\end{array}$ \\
\hline $\begin{array}{r}5849 \\
69873\end{array}$ & Chaco, Paraguay & F. Felippone. \\
\hline 75340 & Sierra de los Aios, Urugua & Do. \\
\hline
\end{tabular}

OPHIODES VERTEBRALIS Bocourt

1881. Ophiodes vertebralis Bocourt, Miss. Sci. Mexique Amer. Cent., p. 459 (type locality, southern Brazil and Uruguay).

Eastern South America.-Three specimens, Nos. 17534-36, with doubtful locality data, collected by H. E. Ames.

\section{Family TEIIDAE}

\section{Genus AMEIVA Meyer}

The writers are now engaged in the preparation of a complete taxonomic revision of the genus Ameiva, but are unable to present the final results pertaining to the South American forms at this time.

\section{AMEIVA AMEIVA AMEIVA (Linnaeus)}

1758. Lacerta ameiva Linnaeus, Syst. Nat., ed. 10, vol. 1, p. 202 (type locality, Brazil).

1915. Ameiva ameiva ameiva Barbour and NoBle, Bull. Mus. Comp. Zoöl., vol. 59, p. 462.

Among the specimens in the collection of the United States National Museum listed below, Nos. 22526 and 60685 may be regarded as intergrades between ameiva and praesignis. The white spotting in these rises higher on the back than in typical ameiva, but less than in typical praesignis.

\begin{tabular}{|c|c|c|c|}
\hline No. & Locality & Date & Collector \\
\hline 66664 & via_ & & $\mathrm{ST}$ \\
\hline & $\mathrm{d}, \mathrm{Bol}$ & & t Gibbons. \\
\hline 3960 & an, 1 & & J. 1 \\
\hline & eraes, $\mathrm{B}$ & & and Copeland \\
\hline & $\mathrm{uco}, \mathrm{Br}$ & Dec.,- 1895 & Hurter collection. \\
\hline 79 & $\begin{array}{l}\text { Par } \\
\text { San }\end{array}$ & & C. J. \\
\hline $\begin{array}{l}60685 \\
60691\end{array}$ & Sal & Dec. - 1915 & $\begin{array}{l}\text { nund } \\
\text { Do. }\end{array}$ \\
\hline & Par & & Captain Page. \\
\hline $\begin{array}{r}22526 \\
27787-8\end{array}$ & La Guaira, Venezuela & $\begin{array}{l}\text { June } 25,1895 \\
\text { July }-, 1900\end{array}$ & $\begin{array}{l}\text { W. Robinson. } \\
\text { M. W. Lyon, jr., ar }\end{array}$ \\
\hline $72752-54$ & $\begin{array}{l}\text { San Juan de } \\
\text { gua, Vene }\end{array}$ & & H. Pittier. \\
\hline
\end{tabular}




\section{AMEIVA AMEIVA PRAESIGNIS (Baird and Girard)}

1852. Cnemidophorus praesignis BaIrd and GIrard, Proc. Acad. Nat. Sci. Philadelphia, p. 129 (type locality, Panama).

1915. Ameiva ameiva praesignis Barbour and Noble, Bull. Mus. Comp. Zoöl., vol. 59, p. 468 .

In the specimens listed below the white spots are continued dorsally to the vertebral line, so the lizards are classified as praesignis.

Peru.-Five specimens, Nos. 60686-90, collected at Santa Ana by E. C. Erdis in December, 1915.

\section{AMEIVA ATRIGULARIS (Garman)}

1887. Ameiva surinamensis atrigularis Garman, Bull. Essex Inst., vol. 19, pp. 2-3 (type locality, Trinidad).

1915. Ameiva atrigularis Barbour and Noble, Bull. Mus. Comp. Zoöl., vol. 59, p. 460 .

Trinidad.-Four specimens, Nos. 17721-24, collected by G. T. Wayman in 1891.

\section{AMEIVA BIFRONTATA BIFRONTATA (Cope)}

1862. Ameiva bifrontata Cope, Proc. Acad. Nat. Sci. Philadelphia, p. 67 (type locality, St. Thomas, W. I., probably ineorrect, and New Grenada, probably correct).

Margarita Island, Venezuela.-One specimen, No. 22530, collected by W. Robinson on June 30, 1895.

\section{AMEIVA FESTIVA (Lichtenstein)}

1856. Cnemidophorus festivus Lichtenstein, Nomencl. Mus. Zoöl. Berol., p. 13 (type locality, Veragoa).

1862. Ameiva eutropia Cope, Proc. Acad. Nat. Sci. Philadelphia, p. 62 (type locality, Truando River, Colombia).

Colombia.-Two specimens, No. 4320, co-types of Ameiva eutropia Cope, from the Truando River Valley, northwestern part, collected by A. Schott.

\section{AMEIVA SEPTEMLINEATA Duméril}

1851. Ameiva septemiineata DumérIL, Cat. Méth. Coll. Reptiles (Paris), p. 114 (type locality, South America).

1868. Holcosus bridgesii Cope, Proc. Acad. Nat. Sci. Philadelphia, p. 306 (type locality, not mentioned in original description).

1915. Ameiva bridgesii Barbour and Noble, Bull. Mus. Comp. Zoöl., vol. 59, p. 478 .

The Ameiva septemlineata of Barbour and Noble (1915) is not this species, but Ameiva edracantha Bocourt.

Ecuador.-Two specimens, No. 33860 from the Alausi Valley, collected by S. A. Davis, and No. 60522 from San Rafael, taken by J. B. Rorer. 


\section{Genus ANADIA Gray}

As indicated by Loveridge (1929), it seems inadvisable to attempt anything like a generic revision of these highly variable and little known lizards at this time. From all appearances, it is very likely that future workers will make great changes in the nomenclature of this genus.

\section{ANADIA BITAENIATA Boulenger}

1903. Anadia bitaeniata Boulenger, Ann. Mag. Nat. Hist., ser. 7, vol. 12, p. 430 (type locality, Escorial and Culata, Venezuela).

Two Venezuelan specimens, U.S.N.M. Nos. 66842-43, collected under rocks in damp places at 10,300 feet altitude in the valley of the Chama River in December, 1923, by E. P. de Bellard, may as well be referred to this species as to any other, since many of their characters are those described by Boulenger. Their variation may be outlined as follows: Frontonasal of uneven width, somewhat narrower than long; nasal entire; 4 pairs of postmentals, the anterior 2 in contact medially (No. 68843), or 3 postmentals on one side of the median suture and 4 on the other, the anterior (2 on one side and 1 on the other) of these "paired" units in contact, and the 2 posterior pairs separated by the anterior gular granules (No. $68842) ; 14$ to 17 scales between the chin shields and the edge of the collar; 4 anterior preanals, 6 posterior; 7 or 8 femoral pores on each side; 34 scale rows around the middle of the body; 48 to 52 segments from the occiput to the base of the tail; two supraoculars (sic!); 8 to 10 large collar scales; blackish brown above, slate below.

\section{Genus BACHIA Gray}

\section{BACHIA INTERMEDIA Noble}

1921. Bachia intermedia NoBLE, Ann. New York Acad. Sci., vol. 29, p. 142 (type locality, Perico, Department of Cajamarca, Peru).

Peru.-One paratype, No. 59927, collected at Perico, the type locality, by the Harvard-Peruvian expedition in 1916.

\section{BACHIA PARKERI Ruthven}

1925. Bachia parkeri Ruthven, Proc. Boston Soc. Nat. Hist., vol. 38, p. 103 (type locality Chenapowu River, "on the upper Potaro River”, British Guiana).

This name was primarily based on five specimens from the type locality. With these was associated a sixth specimen in the United States National Museum, No. 65437, collected at Rio Tiquiè, southeastern Colombia, by Mr. G. McCreagh. Its chief characteristics may be summarized as follows: Supraocular 1 ; superciliaries 2 ; interparietal absent; upper labials separated from parietals; one pair of 
postmentals in contact medially; longitudinal body scale rows in 26 series; transverse body segments 48 to 50 ; fore limb with 3 unclawed digits, hind limb undivided.

\section{Genus CALLOPISTES Gravenhorst}

\section{CALLOJISTES FLAVIPUNCTATUS (Dumeril and Bibron)}

1839. Aporomera flavipuncíata DumÉril and Bibron, Erp. Gén., vol. 5, p. 72 (type locality, the "Nouveau-Monde").

1845. Callopistes flavipunctatus Gray, Cat. Liz. Brit. Mus., p. 17.

Peru.-One specimen, No. 38559, received from R. E. Coker.

CALLOPISTES MACULATUS Gravenhorst

1838. Callopistes maculatus Gravenhorst, Nova Acta Acad. Caes. Leop.-Carol., vol. 18, pt. 2, p. 744 (type locality, Chile).

Chile.-Three specimens, No. 5844, taken at Atacama by C. H. Reynolds, No. 17537, secured on San Lorenzo Island (?) by H. E. Ames, and No. 5517, found at Santiago by Lieut. J. M. Gilliss.

\section{Genus CNEMIDOPHORUS Wagler}

\section{CNEMIDOPHORUS LEMNISCATUS LEMNISCATUS (Linnaeus)}

1758. Lacerta lemniscata Linnaeus, Syst. Nat., ed. 10, vol. 1, p. 209 (type locality, "Guinea," lapsus calami for Guiana).

1839. Cnemidophorus lemniscatus DumérIL and BiBron, Erp. Gén., vol. 5, p. 128.

Brazil.-One specimen No. 6008, from the Amazon Valley, collected by Lieutenant Herndon.

Colombia.-Two specimens, No. 4352, secured at Cartagena, New Grenada, by A. Schott, and No. 12240, taken at Truando by the same collector.

Venezuela.-Fifteen specimens, No. 58452, from the Hurter collection, Nos. 22528-29, taken at La Guaira on June 21, 1895, by W. Robinson, No. 27786 taken on July 2, 1900, and 27809-16 taken on July 25, 1900, at La Guaira by M. W. Lyon, jr. and W. Robinson, Nos. 27829-30, found near the Rio Chico 100 miles east of La Guaira by L. Goldschmidt, and No. 72751, from San Juan de los Morros, Aragua, secured by $\mathrm{H}$. Pittier.

\section{CNEMIDOPHORUS MURINUS MURINUS (Laurenti)}

1768. Seps murinus Launenti, Synops. Reptil., p. 63 (type locality, "Guiana," probably incorrect).

1834. Cnemidophorus murinus Wiegmann, Herpetologia Mexicana, p. 27.

Curaçao, Dutch Leeward Islands.-Three specimens, No. 13680, secured February 10-18, 1884, United States Fish Commission steamer Albatross, No. 27789, taken June 30, 1900, by M. W. Lyon, jr. and W. Robinson, and No. 22527, collected by W. Robinson on July $30,1895$. 


\section{Genus DRACAENA Daudin}

\section{DRACAENA GUIANENSIS Daudin}

1803. Dracaena guianensis Daudin, Hist. Nat. Reptiles, vol. 2, p. 423 (type locality, Saint-François River, Brazil).

South America.-One specimen, No. 71729, received from A. Foehl, jr.

\section{Genus EUSPONDYLUS Tschudi}

1845. Euspondylus Tschud, Fauna Peruana, Herpet., p. 41 (type species, E. maculatus Tschudi).

1881. Prionodactylus O'Shaughnessy, Proc. Zool. Soc. London, p. 231 [type species, Cercosaura (Prionodactylus) manicata O'Shaughnessy].

Since the keeling of the dorsal scales is highly variable in specimens belonging to this section, it has been necessary to unite Euspondylus and Prionodactylus.

\section{EUSPONDYLUS OCKENDENI HOLMGRENI (Andersson)}

1914. Prionodactylus holmgreni Andersson, Arkiv. Zool., vol. 9, no. 3, p. 9 (type locality, San Fermin, northwest Bolivia).

This lizard is very closely allied to $E$. ockendeni ockendeni of adjacent areas in Peru.

A single specimen of holmgreni, U.S.N.M. No. 59013, which has no definite locality data, shows the characters of the subspecies, as follows: 3 supraoculars; nasal plate divided; 1 frontonasal; 27 transverse series of ventral plates; 37 scales from the occiput to the base of the tail; 30 scales around the middle of the body.

\section{EUSPONDYLUS OCKENDENI OCKENDENI (Bouienger)}

1907. Prionodactylus ockendeni Boulenger, Ann. Mag. Nat. Hist., ser. 7. vol. 19, p. 486 (type locality, Carabaya, eastern Peru).

1911. Prionodactylus spinalis Boulenger, Ann. Mag. Nat. Hist., ser. 8, vol. 7, p. 23 (type locality, Huancabamba, eastern Peru).

Euspondyli in southern Peru show a range of variation which includes the diagnoses of both ockendeni and spinatis. Barbour and Noble (1921) have shown that the type locality of spinatis is no doubt in error and that the species may be considered as belonging to the area of southern Peru. Therefore, the previously described ockendeni takes precedence over spinatis.

The variation exhibited by the specimens listed below may be summarized as follows: Supraoculars 3 or 4 ; nasal plate divided or entire; 1 frontonasal; 20 transverse series of ventral plates; 40 to 45 scales from the occiput to the base of the tail; 40 to 46 scales around the middle of the body; dorsal scales smooth or keeled, often smooth anteriorly and keeled posteriorly. 
The specimens of ockendeni in the collection of the United States National Museum may be listed as follows:

\begin{tabular}{|c|c|c|c|}
\hline No. & Locality & State & Collector \\
\hline $60663-72$ & $\begin{array}{l}\text { Occobamba River Valley, at } \\
\text { Tocopoqueyu, southern Peru. }\end{array}$ & July 25,1915 & Edmund Heller. \\
\hline 60729 & $\begin{array}{l}\text { Ollantaytambo, Peru, } 9,400 \\
\text { feet. }\end{array}$ & July 14,1915 & Do. \\
\hline 60745 & Cosireni River, southern Peru_. & Aug. - 1915 & Do. \\
\hline
\end{tabular}

\section{EUSPONDYLUS VERTEBRALIS (O'Shaughnessy)}

1879. Cercosaura (Pantoảactylus) vertebralis O'SHadghnessy, Ann. Mag. Nat. Hist., ser. 5, vol. 4, p. 298 (type locality, Intac, Ecuador).

1885. Prionodactylus vertebralis Boulenger, Cat. Liz. Brit. Mus., vol. 2, p. 394, pl. 21 , fig. 2 .

The specimens listed below show the following variation: 2 or 3 supraoculars; nasal plate divided or entire; 1 frontonasal; 20 transverse series of ventral plates; 32 to 34 scales from the occiput to the base of the tail; 33 to 38 scales around the middle of the body.

Colombia.-Two specimens, No. 75968, collected at the Quindio Mountains, Department of Tolima, and No. 75967, collected at San Pedro, near Medellin, both secured by Nicéforo Maria.

\section{Genus GYMNOPHTHALMUS Merrem GYMNOPHTHALMUS LAEVICAUDUS (Cope)}

1870. Tretioscinus laevicaudus Cope, Proc. Amer. Philos. Soc., vol. 11, p. 557 (type locality, Occidental Department, Nicaragua).

1876. Epaphelus sumichrastii Cope, Journ. Acad. Nat. Sci. Philadelphia, ser. 2, vol. 8, p. 115 (type locality, Costa Rica).

1885. Gymnophthalmus sumichrasti Bocourt, Miss. Sci. Mexique et Amer. Cent., Rept., p. 471, pl. $20 \mathrm{H}$, fig. 2.-Boulenger, Cat. Liz. Brit. Mus., vol. 2, p. 428.-Ruthien, Misc. Publ. Mus. Zool. Univ. Michigan, no. 8, 1922, p. 64.

1885. Tretioscincus laevicauda Boulenger, Cat. Liz. Brit. Mus., vol. 2, p. 426. 1887. Gymnophthalmus laevicaudus Cope, Bull. U. S. Nat. Mus., no. 32, p. 46.

As shown by Cope (1887), his Gymnophthalmus sumichrastii and his Tretioscincus laevicauda, which were recognized as distinct from each other by Boulenger, 1885, and certain later writers, are one and the same species. Cope's error in making the original generic liagnosis of taevicaudus and his subsequent failure to describe its true generic characters no doubt led Boulenger (1885) to retain laevicaudus as a form of Tretioscincus instead of referring it to the genus Gymnophthalmus.

A specimen of laevicaudus, U.S.N.M. No. 72755 , collected at San Juan de los Morros, Aragua, Venezuela, by H. Pittier may be de- 
scribed as follows: Nasal entire; prefrontals in moderate contact; supraoculars 2 , the posterior section extremely small; dorsal scales smooth; longitudinal scale rows, 12 ; segments from the occipital region to the base of the tail, 32 or 33 ; femoral pores four on each thigh; back and sides without trace of lines; under surfaces light; tail light brownish.

\section{GYMNOPHTHALMUS LINEATUS (Linnaeus)}

1758. Lacerta lineata Linnaeus, Syst. Nat., ed. 10, vol. 1, p. 209 (type locality, Zeilona).-Andersson, Bihang Svenska Vet.-Akad. Handl., vol. 26, sect. 4, No. 1, 1900 , p. 16 (systematic consideration of the type specimens).

1766. Lacerta quadrilineata Linnaeus, Syst. Nat., ed. 12, vol. 1, p. 371 (type locality, North America?).

1768. Seps lineatus Laurenti, Synops. Reptil., p. 60 (type locality, Zeilona).

1820. Gymnophthalmus quadrilineatus Merrem, Syst. Amph., p. 74, (South America).-Duméril and Bibron, Erp. Gén., vol. 5, 1839, p. 820.Boulenger, Cat. Liz. Brit. Mus., vol. 2, 1885, p. 427.-Ruthyen, Misc. Publ. Mus. Zool. Univ. Michigan, No. 8, 1922, p. 64 ; Occas. Pap. Mus. Zool. Univ. Michigan, No. 143, 1923, p. 9.-Mertens, Senckenbergiana, vol. 6, 1924, p. 181.-WERNER, Zeitschr. Wiss. Zool., vol. 125, 1925, p. 538.

1900. Gymnophthalmus lineatus Andersson, Bihang Svenska Vet.-Akad. Handl., vol. 26 , sect. 4 , No. 1 , p. 16.

This species was originally described as Lacerta lineatus by Linnaeus in the tenth edition of the Systema Naturae, but its name was changed to $L$. quadrilineata in the twelfth edition of that work. Therefore, as maintained by Andersson (1900), who has examined the type specimens in addition to the available literature, the form should be known by the earlier name, or, in modern nomenclature, as Gymnophthalmus lineatus (Linnaeus).

Two specimens, U.S.N.M. Nos. 64170-71, collected on the island of Curaçao by T. Gaerste, show the following variations: Nasals entire, or with a faint indication of a lower suture; prefrontals in contact; supraoculars 2 , the posterior 1 very small; dorsal scales smooth; 15 scale rows around the middle of the body; about 35 segments from the occiput to the base of the tail; back with four faint lines; light below; tail salmon.

\section{Genus KENTROPYX Spix}

\section{KENTROPYX CALCARATUS Spix}

1825. Kentropyx calcaratus Spix, Spec. Nov Lacert. Brasil., p. 21 (type locality, "Itapicurú, in provincia Maranhao", Brazil).

1868. Centropyx pelviceps Cope, Proc. Acad. Nat. Sci. Philadelphia p. 98 (type locality, "Itapicurú, in provincia Maranháo," Brazil).

The two specimens listed below apparently show no specific differences. The small specimen from Peru has keeled dorsal scales, 
so it can not be referred to $K$. altamazonicus Cope, which, after all, may prove to be nothing but a synonym of calcaratus.

Brazil.-One specimen, No. 28952, collected at Hyutaihan, Lower Amazonia, by J. B. Steere.

Peru.-One specimen, No. 60744, taken at an elevation of 1800 feet, in the valley of the Rio Comberciato, near the great bend of the Rio Urubamba by Edmund Heller in September, 1915.

\section{KENTROPYX INTERMEDIUS (Gray)}

1831. Teius (Centropyx) intermedius GraY, Synops. Rept., in Griffith's “ Cuvier's Animal Kingdom,” p. 31 (type locality, Surinam).

Although the dorsal scales in the specimen listed below are strongly imbricate, those in specimens in the collection of the American Museum show not only transition stages, but juxtaposition as well.

British Guiana.-One specimen, No. 58462, from the Hurter collection, taken in 1902.

\section{Genus PANTODACTYLUS Duméril and Bibron}

\section{PANTODACTYLUS BUCKLEYI BUCKLEYI (O'Shaughnessy)}

1881. Leposoma buckleyi O'Shaughnessy, Proc. Zool. Soc. London, p. 233 (type locality, Canelos, Ecuador).

1885. Alopoglossus buckleyi Boulenger, Cat. Liz. Brit. Mus., vol. 2, p. 385.

This form is very closely allied to $P$. buckleyi festae Peracca (1904) from which it differs in having the posterior pair of chin shields entirely separated by granules instead of being in contact with each other, at least anteriorly.

A specimen, No. 20613, collected at Plaza de Oro, 200 feet above sea level in the Santiago River Valley, Ecuador, by M. B. Kerr, is apparently referable to this form. It shows the following characters: 28 rows of scales around the middle of the body; 30 scales from the occiput to the base of the tail; 8 rows of transverse gulars, 20 rows of transverse ventrals, and therefore 28 transverse series of plates from the chin shields to the preanal region; femoral pores 7 on each side; ventral plates nearly square, wider in front than behind; chin shields in 3 pairs, the posterior pair nearly separated by granules; temporal scales more or less distinctly keeled, the keeling more pronounced posteriorly.

\section{PANTODACTYLUS SCHREIBERSII (Wiegmann)}

1834. Cercosaura schreibersii Wiegmann, Herpetologia Mexicana, p. 10 (type locality, Brazil).

1863. Pantodactylus bivittatus Cope, Proc. Acad. Nat. Sci. Philadelphia, p. 103 (type locality, Paysandá, Uruguay).

1885. Pantodactyhus schreibersii Boulenger, Cat. Liz. Brit. Mus., vol. 2, p. 388.

There may be either three or four pairs of chin shields in this species. 
The specimens of schreibersii in the collection of the United States National Museum may be listed as follows:

\begin{tabular}{|c|c|c|c|}
\hline No. & Locality & Date & Collector \\
\hline $\begin{array}{r}52599 \\
70486 \\
73915,68034 \\
38112-13 \\
31279-80 \\
65528\end{array}$ & $\begin{array}{l}\text { Cordoba, Argentina. } \\
\text { Uruguay } \\
\text { Montevideo, Uruguay } \\
\text { Punta Carretas, Montevideo } \\
\text { Uruguay. } \\
\text { Paysandú, Paraguay (co- } \\
\text { types of P. bivittatus Cope) } \\
\text { Rincon del Pino, San José, } \\
\text { Uruguay. }\end{array}$ & Nov. 17,1907 & $\begin{array}{l}\text { Mr. Reed. } \\
\text { F. Felippone. } \\
\text { Do. } \\
\text { J. Tremoleras. } \\
\text { Dr. H. W. Kennedy } \\
\text { F. Felippone. }\end{array}$ \\
\hline
\end{tabular}

\section{Genus PHOLIDOBOLUS Peters}

\section{PHOLIDOBOLUS MONTIUM (Peters)}

1862. Ecpleopus (Pholidobolus) montium PeтErs, Abhandl, Akad. Wiss. Berlin, p. 196 (type locality, Quito, Ecuador).

Ecuador.-One specimen, No. 71112, collected at Ibarra.

\section{Genus PROCTOPORUS Tschudi}

1845. Proctoporus Tschud, Fauna Peruana, Herpet., p. 43 (type species, $P$. pachyurus Tschudi).

1862. Oreosaurus Peters, Abhandl. Akad. Wiss. Berlin, p. 201 [type species, Ecpleopus (Oreosaurus) luctuosus Peters].

Andersson (1914) is followed in regarding Oreosaumus Peters (1862) as a synonym of Proctoporus Tschudi (1845).

\section{PROCTOPORUS ANOMALUS (Barbour and Noble)}

1921. Oreosaurus anomalus Barbour and Nobie, Proc. U. S. Nat. Mus., vol. 58, p. 614 (type locality, San Fernando, Rio San Miguel, southern Peru).

This lizard appears to differ from $P$. ocellifer, with which it may have to be united, only in the possession of supranasal plates. This unusual feature is unexpected in Proctoporus and, as suggested by the specific name, it may be but an abnormality. The type specimen of anomalus has been added to the collection of the United States National Museum under the number 60704, from San Fernando, 4,500 feet, Edmund Heller, collector.

\section{PROCTOPORUS PETERSI (Boettger)}

1878. Ecpleopus (Oreosaurus) petersi BoETtger, Bericht. Offenbach. Ver. Naturkunde, Nos. 17 and 18, Miitheilungen, p. 9, pl. 1, fig. 2 (type locality, Province of Pará, Brazil, no doubt in error).

1885. Oreosaurus petersii Boulenger, Cat. Liz. Brit. Mus., vol, 2, p. 411. 
Specimens of this form from the same locality may show both smooth and keeled dorsal scales on the same or on different individuals ( Nusta Hispaña).

The variation in the specimens of this species in the collection of the United States National Museum has been well discussed by Stejneger (1913) and Barbour and Noble (1921).

\begin{tabular}{|c|c|c|c|}
\hline No. & Locality & Date & Collector \\
\hline $\begin{array}{r}60726-27 \\
60748\end{array}$ & $\begin{array}{l}\text { Torenton, Peru, } 10,700 \text { feet.-.- } \\
\text { Nusta Hispaña, Peru (type of } \\
\text { Proctoporus obesus). }\end{array}$ & May 10,1915 & $\begin{array}{l}\text { E. Heller. } \\
\text { E. C. Erdis. }\end{array}$ \\
\hline $\begin{array}{r}60699-700 \\
60719 \\
49549 \\
60746 \\
49551-52\end{array}$ & $\begin{array}{l}\text { Nusta Hispaña, Peru } \\
\text { Ollantaytambo, Peru, } 9,400 \text { feet. } \\
\text { Ollantaytambo, Peru. } \\
\text { Ollantaytambo, Peru, } 9,400 \text { feet- } \\
\text { Tincochchaca, Peru (Type and } \\
\text { paratype of Oreosaurus lacer- } \\
\text { tus). }\end{array}$ & $\begin{array}{lr}\text { June } & 11,1915 \\
\text { May } & 15,1915 \\
\text { July } & 20,1911 \\
\text { July } & 14,1915 \\
\text { Aug. } & 8,1911\end{array}$ & $\begin{array}{l}\text { Do. } \\
\text { O. F. Cook. } \\
\text { E. Heller. } \\
\text { Do. } \\
\text { Yale-Peruvian } \\
\text { Expendition. }\end{array}$ \\
\hline
\end{tabular}

\section{PROCTOPORUS STRIATUS (Peters)}

1862. Ecpleopus (Oreosaurus) striatus Peters, Abhandl. Akad. Wiss. Berlin, p. 201, pl. 3, fig. 2 (type locality, Santa Fé de Bogotá, Colombia). 1885. Oreosaurus striatus Boulenger, Cat. Liz. Brit. Mus., vol. 2, p. 411. 1885. Proctoporus striatus Cope, Proc. Amer. Philos. Soc., vol. 23, p. 98. 1919. Proctoporus bogotensis Boulenger, Proc. Zool. Soc. London, p. 80 (type locality, Bogotá, Colombia).

A single topotype of this species, U.S.N.M. No. 76969, collected at Bogotá, Colombia, by Nicéforo Maria, shows the following characters : 35 or 36 scales from the occiput to the base of the tail; 33 scales around the middle of the body; 8 to 10 rows of ventral plates, if 10 are counted, the outer reduced in size; 23 transverse series of ventral plates; a femoral pore on each side; 4 supraoculars; 9 or 10 transverse series of gular plates, including the collar; dorsal scales strongly striated; body brownish above.

\section{Genus TEIUS Merrem}

TEIUS TEYOU TEYOU (Daudin)

1803. Lacerta teyou Daudr, Hist. Nat. Reptiles, vol. 3, p. 195 (type locality, Paraguay).

1885. Teius teyou Boulenger, Cat. Liz. Brit. Mus., vol. 2, p. 379.

South America.-Two specimens, Nos. 11712 and 15333. Argentina.-Two specimens, Nos. 22754-55, from Corrientes.

Uruguay-Seven specimens, Nos. 70482-84 and 73533 from Uruguay, No. 73534 from Montevideo, No. 65559 from Carrasco, Montevideo, and No. 70485 from Paysandú, all collected by F. Felippone. 


\section{Genus TRETIOSCINCUS Cope}

\section{TRETIOSCINCUS BIFASCIATUS (Duméril)}

1851. Heteropus bifasciatus Duméril, Cat. Méth. Coll. Reptiles, Mus. Paris, p. 182 (type locality, "Vallée de la Madeleine, Nouvelle-Grenade", northeastern Colombia).

1864. Tretioscincus bifasciatus Cope, Proc. Acad. Nat. Sci. Philadelphia, p. 229.

Venezuela.-One specimen, No. 61226, collected by Theodore de Boog in Perija, with 16 scale rows around the body and 4 femoral pores on each thigh.

\section{Genus TUPINAMBIS Daudin \\ TUPINAMBIS NIGROPUNCTATUS Spix}

1825. Tupinambis nigropunctatus SpIx, Spec. Nov. Lacert. Brazil, p. 18 (type locality, Brazil).

Brazil.-Three specimens, No. 38114, supposedly from Para, and Nos. 28953-54, taken at Hyutaihan by J. B. Steere.

British Guiana.-One specimen, No. 12548, brought from Surinam by C. J. Hering.

Peru.-Three specimens, Nos. 60678-80, found in the Valley of the Rio Comberciato, near the great bend of the Rio Urubamba at an altitude of 1,800 feet by Edmund Heller in September, 1915.

Trinidad.-Three specimens, Nos. 17551, 17719, and 32136, collected at Port of Spain by G. T. Wayman.

\section{TUPINAMBIS RUFESCENS (Günther)}

1871. Tejus rufescens Günther, Proc. Zool. Soc. London, p. 541 (type locality, Mendoza, Argentina).

Argentina-Six specimens, Nos. 73506-508, collected by the Byerer Bros., No. 22735 from the Province of Buenos Aires, No. 12315 from Rio Vermejo, received from the La Plata expedition, and No. 47952 from Santa Fe, Rio Salada, the latter collected by W. Frakes.

TUPINAMBIS TEGUIXIN (Linnaeus)

1758. Lacerta teguixin Linnaeus, Syst. Nat., ed. 10, vol. 1, p. 208 (type locality, South America).

Brazil.-Three specimens, No. 12150, collected by Captain Page, No. 59056, taken in 1905 from Bahia, and No. 58618 from Santa Catharina, the last two being part of the Hurter collection. 


\section{Family AMPHISBAENIDAE}

\section{Genus AMPHISBAENA Linnaeus}

\section{AMPHISBAENA ALBA Linnaeus}

1758. Amphisbaena alba Linnaeus, Syst. Nat., ed. 10, vol. 1, p. 229 (type locality, America).

Trinidad.-One specimen, No. 5788, collected by Prof. Theodore Gill.

\section{AMPHISBAENA BOHLSII Boulenger}

1894. Amphisbaena bohlsii Boulenger, Ann. Mag. Nat. Hist., ser. 6, vol. 13, p. 344 (type locality, Asuncion, Paraguay).

Paraguay.-One specimen, No. 11259, collected by E. Palmer.

\section{AMPHISBAENA CAMURA Cope}

1862. Amphisbaena camura Cope, Proc. Acad. Nat. Sci. Philadelphia, p. 350 (type locality, Paraguay).-Boulenger, Ann. Mag. Nat. Hist., ser. 6, vol. 13,1894 , p. 344 .

The inadequate original description of this form has been amplified by Boulenger (1894), who incorrectly synonymized it with Amphisbaena darwinii in 1885. One type specimen has 76 scales in an annulus at the center of the body.

Paraguay.-Two co-types, No. 5860, collected by Capt. Thomas J. Page.

\section{AMPHISBAENA DARWINII Duméril and Bibron}

1839. AmphisbGena darwinii DumérIL and BIBron, Erp. Gén., vol. 5, p. 490 (type locality, Montevideo, Uruguay).

The specimens of this lizard in the collection of the United States National Museum may be listed as follows:

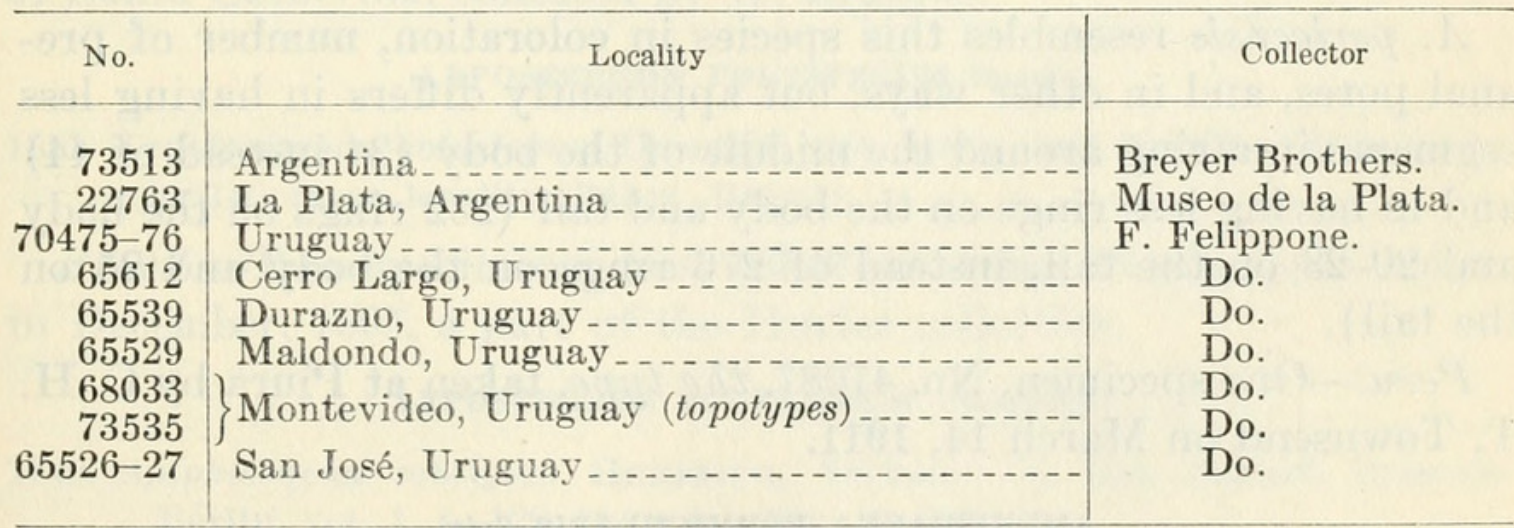




\section{AMPHISBAENA FULIGINOSA Linnaeus}

1758. Amphisbaena fuliginosa Linnaeus, Syst. Nat., ed. 10, vol. 1, p. 229 (type locality, America).

The specimens of Amphisbaena futiginosa in the collection of the United States National Museum may be listed as follows:

\begin{tabular}{|c|c|c|c|}
\hline No. & Locality & Date & Collector \\
\hline $\begin{array}{r}12453,12508 \\
7364 \\
6118 \\
14030 \\
58739 \\
5751 \\
5787\end{array}$ & $\begin{array}{l}\text { South America } \\
\text { Pará, Brazil } \\
\text { Surinam } \\
\text { Ecuador } \\
\text { Surinam } \\
\text { Trinidad } \\
\text { Trinidad }\end{array}$ & $\begin{array}{c}\text { Dec. } 18,1884 \\
1899\end{array}$ & $\begin{array}{l}\text { B. B. Austin. } \\
\text { C. J. Hering. } \\
\text { W. H. Jones. } \\
\text { J. Hurter. } \\
\text { Professor Thomas. } \\
\text { Theodore Gill. }\end{array}$ \\
\hline
\end{tabular}

\section{AMPHISBAENA PERICENSIS Noble}

1921. Amphisbaena pericensis Noble, Ann. New York Acad. Sci., vol. 29, p. 141 (type locality, Perico, Peru).

Peru.-Four specimens, Nos. 59926, 60057-58 and 75970, paratypes, collected at Perico by G. K. Noble in 1916.

\section{AMPHISBAENA PLUMBEA Gray}

1872. Amphisbaena plumbea Gray, Cat. Shield Reptiles Brit. Mus., vol. 2, p. 36 (type locality, Mendoza, Argentina).

Argentina.-Two specimens, No. 52971, a topotype from Mendoza, collected by Renato Sanzin in 1915, and No. 22764, received from Museo de la Plata.

\section{AMPHISBAENA TOWNSENDI Stejneger}

1911. Amphisbaena townsendi Stejneger, Proc. U. S. Nat. Mus., vol. 41, p. 283 (type locality, Piura, Peru).

A. pericensis resembles this species in coloration, number of preanal pores, and in other ways, but apparently differs in having less segments in a ring around the middle of the body (34 instead of 44) and in having less rings on the body and tail (232 rings on the body and $20-23$ on the tail, instead of 276 rings on the body and 25 on the tail).

Peru.-One specimen, No. 47087, the type, taken at Piura by C. H. I. Townsend on March 14, 1911.

\section{AMPHISBAENA VERMICULARIS Spix}

1824. Amphisbaena vermicularis SpIx, Spec. Nova Serp. Brasil., p. 73 (type locality, Province of Bahia, Brazil).

Brazil.-Two specimens, No. 6035, secured at Para by C. A. Hapler. These examples differ in having a slightly higher scale count than that listed by Boulenger (1885) for the species, namely: 
44 segments in an annulus at the middle of the body, 22 above and 22 below ; 227 rings on the body and 30 on the tail.

\section{Genus ANOPSIBAENA Stejneger}

\section{ANOPSIBAENA KINGII (Bell)}

1833. Anops kingii BeLL, Proc. Zool. Soc. London, p. 99 (type locality, South America).

South America.-One specimen, No. 17550, collected by H. E. Ames.

Argentina.-One specimen, No. 16619, from Cordova, collected by H. Edwards.

\section{Genus LEPOSTERNON Spix}

1824. Leposternon SpIx, Spec. Nov. Serp. Brasil., p. 70. 1830. Lepidosternon WAgLER Syst. Amph., p. 197.

\section{LEPOSTERNON BOULENGERI Bosttger}

1885. Lepidosternon boulengeri BoetTger, Zeitschr. f. Naturw., vol. 58, p. 220 (type locality, Paraguay).

In his key (1885), Boulenger says that only the anterior point of the frontal of this lizard is in contact with the rostral, but the three specimens listed below show that it may be rather broadly in contact at times.

Argentina.-Three specimens, Nos. 73510-12, collected by the Breyer Brothers.

\section{LEPOSTERNON MICROCEPHALUM Spix}

1824. Leposternon microcephalus SpIx, Spec. Nov. Serp. Brasil., p. 70 (type locality, Rio de Janerio, Brazil).

Brazit.-Five specimens, No. 58737 from the Hurter collection, and Nos. 40221-24 from (Rio Humboldt, Cerro do Mar), Province of Santa Catherina, collected by W. Erhardt.

\section{LEPOSTERNON POI.YSTEGUM Duméril}

1851. Lepidosternon polystegum Dumérா, Cat. Méth. Coll. Reptiles, Mus. Paris, p. 149 (type locality, Bahia, Brazil).

Brazil.-Two specimens, Nos. 58347-48, from Pernambuco, taken in December, 1895, a part of the Hurter collection.

\section{LEPOSTERNON SCUTIGERUM (Hemprich)}

1820. Amphisbaena scutigera Hemprich, Verhandl. d. Ges. Naturf. Freunde Berlin, vol. 1, p. 129 (type locality, Brazil).

1885. Lepidosternon scutigerum Boulenger, Cat. Liz. Brit. Mus., vol. 2, p. 469.

The head of this form is tinged with dark brown above and the two chief head plates are very well defined and conspicuous.

Brasil.-One specimen, No. 5670 from Rio de Janeiro, taken by the United States Exploring Expedition. 


\section{Family SCINCIDAE}

\section{Genus MABUYA Fitzinger}

\section{MABUYA AGILIS (Raddi)}

1823. Scincus agilis RAdDI, Mem. matem. fisic. Soc. Ital., Modena, vol. 19, No. 18, p. 62 (type locality, Brazil).

1887. Mabuia agilis Boulenger, Cat. Liz. Brit. Mus., vol. 3, p. 190.

Surinam.-Three specimens, Nos. 11042-43 taken in May, 1881, and 11048, collected by C. J. Hering.

Colombia.-One specimen, No. 58160, from Bocas del Toro, from the Hurter collection, taken in September, 1911.

\section{MABUYA DORSOVITTATA (Cope)}

1862. Mabuia dorsovittata Cope, Proc. Acad. Nat. Sci. Philadelphia, p. 350 (type locality, Paraguay).

Argentina.-One specimen, No. 73514, collected by the Breyer brothers.

Paraguay.-One specimen, No. 5405, the holotype, collected by Capt. T. J. Page.

\section{MABUYA FRENATA (Cope)}

1862. Emoea frenata Cope, Proc. Acad. Nat. Sci. Philadelphia, p. 187 (type locality, Paraguay River Valley, Paraguay).

1887. Mabuia frenata Boulenger, Cat. Liz. Brit. Mus., vol. 3, p. 194.

Brasil.-One specimen, No. 28950, from Hyutaihan, Lower Amazonia, collected by J. B. Steere.

Paraguay.-Three specimens, No. 5855, cotypes, collected by Capt. T. J. Page.

\section{MABUYA NIGROPALMATA (Andersson)}

1918. Mabuia nigropalmata Andersson, Arkiv Zool,, vol. 11, no. 16, p. 8 (type locality, "Brazil, Amazonas, Rio Curuea, tributary to R. Javary", and "San Fermin, N. W. Bolivia").

A small skink in the collection of the United States National Museum, No. 13826, secured at Mollendo, Peru, on September 28, 1883 , by Dr. W. H. Jones, is apparently referable to this species. It differs from the common skink, $M$. agitis, and from $M$. punctata (of Tschudi) as well, by the possession of a distinct middorsal light stripe. In addition there are a pair of dorso-lateral light stripes. The dorsal ground color is dark brown and the ventral parts are yellowish, with a bluish tinge. The anterior head scutes are injured, but it appears that the frontoparietal plate is entire as in nigropalmata and frenata. There are 30 scale rows around the middle of the body, a count common to agitis, nigropalmata, and frenata. 


\section{LITERATURE CITEI)}

Amaral, Afranio do.

1925.-South American Snakes in the Collection of the United States National Museum, Proc. U. S. Nat. Mus., vol. 67, pp. 1-30.

Andersson, Lars Gabriel.

1900.-Catalogue of Linnaean Type-Specimens of Linnaeus's Reptilla in the Royal Museum in Stockholm, Bihang till K. Svenska Vet.Akad. Handl., vol. 26, sec. 4, No. 1, pp. 1-29.

1914.-A New Telmatobius and New Teiidoid Lizards from South America. Arkiv f. Zoöl., vol. 9, No. 3, pp. 1-12.

1918.-New Lizards from South America, Archiv f. Zoöl., vol. 11, No. 16, pp. $1-10$.

Baird, Spencer F. and Charles Girard.

1852. - Characteristics of some New Reptiles in the Museum of the Smithsonian Institution, Proc. Acad. Nat. Sci. Philadelphia, pp. 68-70.

Barbour, Thomas.

1914. A Contribution to the Zoögeography of the West Indies, with Especial Reference to Amphibians and Reptiles. Mem. Mus. Comp. Zoöl., vol. 44, No. 2, pp. 209-346.

1916. - Additional Notes on West Indian Reptiles and Amphibians. Proc. Biol. Soc. Washington, vol. 29, pp. 215-220.

1920.-A Leiocephalus Misnamed, Copeia, No. 85, p. 73.

Barbour, Thomas, and G. Kingsley Noble.

1915.-A Revision of the Lizards of the Genus Ameiva, Bull. Mus. Comp. Zoöl. vol., 59, pp. 417-479.

1921.-Amphibians and Reptiles from Southern Peru Collected by the Peruvian Expedition of 1914-1915 under the Auspices of Yale University and the National Geographic Society, Proc. U. S. Nat. Mus., vol. 58, pp. 609-620.

BAUR, G.

1890 - Das Variieren der Eidechsen Gattung Tropidurus auf den GalapagosInseln und Bemerkungen ueber den Ursprung der Inselgruppe. Biol. Centralblatt., vol. 10, pp. 475-484.

BELL, THOMAS.

1826-On a new Genus of Iguanidae, Zool. Journ. (London), vol. 2, pp. 204-208.

1833-Characters of Two New Genera of Reptiles, Proc. Zool. Soc. London, pp. 98-99.

1843-Reptilia, in Zool. "Beagle," pt. 5, pp. 1-47.

Berg, Carlos.

1893-Contribucions al concimento de la Fauna erpetologia Argentina y de los Paises Limitrofes. Anal. Mus. Nac. Buenos Aires (Argentina), vol. 6, pp. 1-35.

Pocourt, F.

1874-Deux Notes sur quelques Sauriens de l'Amerique tropicale. Ann. Sci. Nat. (Paris), vol. 19, art. 4, pp. 1-5.

\section{BOETTGER, OSCAR.}

1878-Studien ueber neue oder wenig bekannte Eidechsen I. Ber. Offenb. Ver. f. Naturk. (1875-77), No. 17-18, pp. 1-12.

1885-Liste von Reptilien und Batrachier aus Paraguay. Zeitschr. f. Naturw., vol. 58, pp. 213-248. 
BOUlenger, G. A.

1885-Catologue of the Lizards in the British Museum, ed. 2, vol. 1, pp. 1-436, pls. 1-32.

1885-Catalogue of the Lizards in the British Museum, ed. 2, vol. 2, pp. 1-497, pls. 1-24.

1885-List of Reptiles and Batrachians sent by Mr. von Ihering from Rio Grande do Sul, Ann. and Mag. Nat. Hist., ser. 5, vol. 15, pp. 191-196.

1887-Catalogue of the Lizards in the British Museum, ed. 2, vol. 3, pp. 1-575, pls. 1-40.

1889-On some Specimens of Lizards in the Zoological Museum of Halle, Proc. Zool. Soc. London, pp. 143-145.

1890 - First Report on Additions to the Lizard Collection in the British Museum, Proc. Zool. Soc. London, pp. 77-86.

1891-Description of a New Genus of Iguanoid Lizards, Ann. Mag. Nat. Hist., ser. 6, vol. 8, pp. 85-86.

1894-List of Reptiles and Batrachians Collected by Dr. J. Bohls near Asuncion, Paraguay, Ann. and Mag. Nat. Hist., ser. 6, vol. 13, pp. 342-348.

1900 -Descriptions of New Batrachians and Reptiles Collected by Mr. P. O. Simons in Peru, Ann. Mag. Nat. Hist., ser. 7, vol. 6, pp. 181-186. 1901-Further Descriptions of New Reptiles Collected by Mr. P. O. Simons in Peru and Bolivia, Ann. Mag. Nat. Hist., ser. 7, vol. 7, pp. $546-549$.

1903-Descriptions of New Lizards in the Collection of the British Museum, Ann. Mag. Nat. Hist., ser. 7, vol. 12, pp. 429-435.

1907-Descriptions of New Lizards in the British Mruseum, Ann. Mag. Nat. Hist., ser. 7, vol. 19 , pp. $486-489$.

1911-Descriptions of New Reptiles from the Andes of South America, preserved in the British Museum, Ann. Mag. Nat. Hist., ser. 8, vol. 7 , pp. 19-25.

1913-Description of a New Lizard and a New Snake from South America, Ann. Mus. Civ. Stor. Nat. Genova, ser. 3, vol. 6, pp. 49-50.

1919 -Descriptions of Two New Lizards and a New Frog from the Andes of Colombia, Proc. Zool. Soc. London, pp. 79-81.

\section{Burmeister, Hermann.}

1861-Reise durch die La Plata-Staaten (1857-1860), vol. 2, pp. 1-538.

COPE, E. D.

1862-Contributions to Neotropical Saurology, Proc. Acad. Nat. Sci. Philadelphia, pp. 176-188.

1862-Catalogue of the Reptiles Obtained During the Explorations of the Parana, Paraguay, Vermejo, and Uruguay Rivers . . etc., Proc. Acad. Nat. Sci. Philadelphia, pp. 346-359.

1863-New American Squamata in the Museum of the Smithsonian Institution, Washington, Proc. Acad. Nat. Sci. Philadelphia, pp. 100-106. 1864 Contributions to the Herpetology of Tropical America, Proc. Acad. Nat. Sci. Philadelphia, pp. 166-181.

1868-An Examination of the Reptilia and Batrachia Obtained by the Orton Expedition to Ecuador and the Upper Amazon, with Notes on Other Species, Proc. Acad. Nat. Sci. Philadelphia, pp. 96-119.

1870-Eighth Contribution to the Herpetolosy of Tropical America, Proc. Amer. Philos. Soc., vol. 11, pp. $533-559$. 
Cope, E. D.-Continued.

1876-Reptiles Brought by Professor James Orton from the Middle and Upper Amazon, and Western Peru, Journ. Acad. Nat. Sci. Philadelphia, ser. 2, vol. 8, pp. 159-188.

1885-Thirteenth Contribution to the Herpetology of Tropical America, Proc. Amer. Philos. Soc., vol. 23, pp. 271-287.

1887-Catalogue of Batrachians and Reptiles of Central America and Mexico, Bull. U. S. Nat. Mus., no. 32, pp. 1-98.

1889-Report on the Batrachia and Reptilia Collected in 1887-1888, Proc. U. S. Nat. Mus., vol. 12, pp. 141-147 (Scientific Results of the Explorations of the U. S. Fish Commission Steamer "Albatross").

DAUDiN, F. M.

1802-Sauriens (part), in "Hist. Nat. des Reptiles", vol. 3, pp. 1-452.

1803-Sauriens (part), in "Hist. Nat. des Reptiles", vol. 4, pp. 1-397.

Duméril, A. M. C., and G. Bibron.

1836-Erpétologie Génerale, vol. 3, pp. 1-517, pl. 1 to 36.

1837-Erpétologie Génerale, vol. 4, pp. 1-571, pl. 37 to 48.

1839 -Erpétologie Génerale, vol. 5, pp. 1-854, pl. 49 to 58.

Duméril, C., and A. DumérIL.

1851-Catalogue méthodique de la Collection des Reptiles, Paris, pp. 1-224.

Fitzinger, L.

1843-Systema Reptilium, pp. 1-106, i-vi.

Garman, Samuel.

1887-On West Indian Teiidae in the Museum of Comparative Zoölogy, Bull. Essex Inst., vol. 19, pp. 1-12.

1892- On the Reptiles Collected by Dr. George Baur near Guayaquil, Ecuador, Bull. Essex Inst., vol. 24, pp. 88-97.

Girard, Charles.

1857-Descriptions of Some New Reptiles, Collected by the United States Exploring Expedition Under the Command of Capt. Charles Wilkes, U. S. N., vol. 4, Proc. Acad. Nat. Sci. Philadelphia, pp. 195-199.

Gravenhorst, J. L. C.

1838-Beiträge zur Genauern Kenntniss einiger Eidechsengattungen. Nova Acta Acad. Caes. Leop.-Carol., vol. 18, pp. 713-784, pls. 44-46.

Gray, J. E.

1828-1830-Spicilegica Zoologica; or Original Figures and Short Systematic Descriptions of New and Unfigured Animals, parts 1 and 2 , pp. 1-12, pls. $1-11$.

1831-A Synopsis of the Species of the Class Reptilia, Appendix to Griffith's "Cuvier's 'Animal Kingdom,", pp. 1-110.

1840 - Catalogue of the Species of Reptiles Collected in Cuba by W. S. MacLeay, Ann. Nat. Hist., vol. 5, pp. 108-115.

1845-Catalogue of the Specimens of Lizards in the Collection of the British Museum, pp. 1-289.

1872-Catalogue of the Shield Reptiles in the Collection of the British Museum. Part II. Emydosaurians, Rhynchocephalia Amphisbaenians.

Guichenot, A.

1855-Reptiles, in Castelnau's "Animaux nouveaux ou rares del' Amerique du Sud (1843-1847)," pp. 1-95. 
GüNTher. A.

1859-List of Cold-blooded Vertebrata Collected by Mr. Fraser in the Andes of Western Ecuador, Proc. Zool. Soc. London, pp. 89-93.

1859-Second List of the Cold-blooded Vertebrata Collected by Mr. Fraser in the Andes of Western Ecuador, Proc. Zool. Soc. London, pp. $402-420$.

1860-Third List of Cold-blooded Vertebrata Collected by Mr. Fraser in Ecuador, Proc. Zool. Soc. London, pp. 233-240.

1871-Description of a New Species of Tejus (Tejus rufescens) from Mendoza, Proc. Zool. Soc. London, pp. 541-543.

Koslowsky, JuLio.

1895-Dos nuevas Lagartijas de la Provincia de Buenos Aires. Revista Mus. La Plata, vol. 6, pp. 417-420.

1896-Enumeracion sistematica $\mathbf{y}$ distribucion geografica de los Reptiles Argentinos, Revista Mus. La Plata, vol. 8, pp. 161-200.

Kuhl, Heinrich.

1820-Beiträge zur Zoölogie und vergleichenden Anatomie. Frankfurt, a. M., pp. 1-213.

LAURENTi, J. N.

1768-Synopsin Reptilium, pp. 1-214.

LESSON, R. P.

1826-In L. I. Duperry's "Voyage autour du Monde . . . sur . . . la Coquille," Atlas, Reptiles, pls. 1-6.

1830 -Reptiles, in L. I. Duperry's “Voyage autour du Monde . . . sur . . . la Coquille," text, vol. 2, pt. 1, pp. 1-157.

Lichenstein, H.

1856-Nomenclator Reptilium et Amphibiorum, Musei Zool Berolinensis, pp. 1-48.

LinNaeus, C.

1758-Systema Naturae, ed. 10.

1766-Systema Naturae, ed. 12.

LOVeridge, Arthur.

1929-A New Anadia from Columbia with Remarks on other Members of the Genus, Proc. Biol. Soc. Wash., vol. 42, pp. 99-102.

Merrem, Blasius.

1820 - Versuch eines Systems der Amphibien, pp. 1-191.

Mertens, Robert.

1924-Herpetologische Mitteilungen, I-VII, Senckenbergiana, vol. 6, pp. $177-185$.

Müller, LORENZ.

1922-Ueber Aperopristis paronae Peracca und die Genera Aperopristis und Liosaurus Duméril et Bibron, Senckenbergiana, vol. 4, pp. 153-159.

Noble, G. K.

1921-Some New Lizards from Northwestern Peru, Ann. New York Acad. Sci., vol. 29 , pp. 133-139.

O'Shaughnessy, A. W. E.

1879-Descriptions of New Species of Lizards in the Collection of the British Museum, Ann. Mag. Nat. Hist., ser. 5, vol. 4, pp. 295-303.

1881-An account of the Collection of Lizards made by Mr. Buckley in Ecuador, Proc. Zool. Soc. London, pp. 227-245, pls. 22-25. 
PARKer, H. W.

1926-The Reptiles and Batrachians of Gorgona Island, Colombia, Ann. Mag. Nat. Hist., ser. 9, vol. 17, pp. 549-554.

Peracca, M. G.

1904-Viaggio del Dr. Enrico Festa nell'Ecuador e Regioni vicine, Rettili ed Amfibii, Bol. Mus. Zool. Univ. Torino, vol. 19, No. 465, pp. 1-41. 1890-Descrizione di una nuova Specie del Gen. Diploglossus Wiegmann, Bol. Mus. Zool. Univ. Torino, vol. 5, No. 77, pp. 1-5.

Peters, W.

1862-Ueber Cercosaura und die mit dieser Gattung verwandten Eidechsen aus Sudamerika, Abhandl. d. k. Akad. Wiss. zu Berlin, pp. 165-225, pls. $1-3$.

1869-Ueber neue Gattungen und Arten von Eidechsen, Monatsber. Berlin Akad. Wiss., pp. 57-66.

1871-Ueber eine von Hrn. Dr. Robert Abenroth in dem Hochlande von Peru gemachte Sammlung von Amphibien, Monatsber. Berlin Akad. Wiss., pp. 57-66.

Reinhardt, J., and C. LÜtKen.

1862-Bidrag til der vestindiske Origes og navnligen til de dansk-vestindiske Oers Herpetologie, Vidensk. Meddel. Nat. Fören, pp. 143-242.

RoUx, JEAN.

1907-Revision de quelques Espécies de Reptiles et Amphibiens du Perou, Rev. Suisse Zool., vol. 15, pp. 293-303.

Ruthien, Alexander G.

1922-The Amphibians and Reptiles of the Sierra Nevada de Santa Marta, Columbia, Misc. Publ. Mus. Zool. Univ. Mich., vol. 8, pp. 1-69.

1923-The Reptiles of the Dutch Leeward Islands, Occas. Pap. Mus. Zool. Univ. Mich., no. 143, pp. 1-10.

1925-Lizards of the Genus Bachia, Proc. Boston Soc. Nat. Hist., vol. 38, pp. 101-109.

1926-The status of Phyllodactylus spatulatus Cope. Occas. Pap. Mus. Zool. Univ. Mich., no. 178, pp. 1-2.

SPIx, J. B. DE.

1825-Animalia Nova sive Species Novae Lacertarum Brasiliam, pp. 1-26. Steindachner, Franz.

1901-Herpetologische und ichthyologische Ergebnisse einer Reise nach Sudamerika mit einer Einleitung von Therese Prinzessin von Baiern, Anz. Akad. Wiss. Wien, vol. 38, pp. 194-196.

STEJNEGER, LEONHARD.

1900-Description of Two New Lizards of the Genus Anolis from Cocos and Malpelo Islands, Bull. Mus. Comp. Zoöl., vol. 36, pp. 161-164, pl. 1.

1901-An Annotated List of Batrachians and Reptiles Collected in the Vicinity of La Guaira, Venezuela, with Descriptions of Two New Species of Snakes, Proc. U. S. Nat. Mus., vol. 24, pp. 179-192.

1909-Batrachians and Reptiles, Reports of the Princeton Univ. Exp. to Patagonia, vol. 3, Zool., pt. 2, pp. 211-224.

1913-Results of the Yale Peruvian Expedition of 1911, Batrachians and Reptiles, Proc. U. S. Nat. Mus., vol. 45, pp. 541-547.

1917-Cuban Amphibians and Reptiles Collected for the United States National Museum from 1899 to 1902, Proc. U. S. Nat. Mus., vol. 53, pp. 259-291. 
Tschudi, J. J. von.

1845-Herpetologie, in "Untersuchungen ueber die Fauna Peruana," pp. 317-380.

Van Denburgh, John, and Joseph R. Slevin.

1913-The Galapagos Lizards of the Genus Tropidurus; with Notes on the Iguanas of the Genera Conolophus and Amblyr-hynchus, Proc. Calif. Acad. Sci., ser. 4, vol. 2, pp. 133-202.

VAN Lidth de Jeude, T. W.

1887-On a Collection of Reptiles and Fishes from the West Indies, Notes from the Leyden Mus., vol. 9, pp. 129-139.

WAGLER, J.

1830-Naturliches System der Amphibien, pp. 1-354.

Werner, Franz.

1896-Die Iguaniden-Gattung Anisolepis Blgr, Verhandl. der k. k. zool.-bot. Ges. Wien, vol. 46 , pp. 470-474.

1901-Reptilien und Batrachier von Ecuador, Verhandl, der k. k. zoöl.-bot. Ges. Wien, vol. 51, pp. 593-602.

1901-Reptilien und Batrachier aus Peru und Bolivien. Abhandl. u. Ber. d. k. Zoöl. Anthr.-Ethn. Mus. Dresden (1900-1901), vol. 9, No. 2, pp. 1-14.

1910-Ueber neue oder seltene Reptilien das Naturhistorischen Museums in Hamburg. II. Eidechsen, Hamburg Jahrb. wiss. Anst., vol. 27 , pp. 1-46.

1913-Neue oder seltene Reptilien und Frosche des Naturhistorischen Museums in Hamburg, Mitt. Naturh. Mus. Hamburg, vol. 30 (1912), pt. 2, zum Jahrb. Hamburg wiss. Anzt., pp. 1-51.

1916-Bemerkungen ueber einige niedere Wirbeltiere der Anden von Kolumbein mit Beschreibungen neuer Arten, Zool. Anz., vol. 47, pp. 301-310.

1925-Zur Kenntnis der Fauna der Insel Bonaire, Zeitschr. f. Wiss. Zool., vol, 125, pp. 533-556.

Wied, Maximilian Prinz zu.

1820-Reise nach Brasilien (1815-1817), vol. 1, pp. 1-380.

1821-Reise nach Brasilien (1815-1817), vol. 2, pp. 1-346.

Wiegmann, A. F. A.

1834-Herpetologia Mexicana ... Pars prima. Saurorum Species, pp. 1-54, pl. 1-10.

1835-Beitrage zur Zoölogie, gesammelt auf einer Reise um die Erde, von Dr. F. J. F. Meyen, VII. Amphibien, Nova Acta Acad. Caes. Leop.-Carol., vol. 17 , pt. 1, pp. 185-268. 


\section{INDEX}

Agama hispida.

Alopoglossus buckleyi

Amblyrhynchus.

cristatus

Ameiva

ameiva ameiva

praesignis.

atrigularis.

bifrontata.

bifrontata.

bridgesii.

edracantha.

eutropia -

festiva.

septemlineata

surinamensis atrigularis

Amphisbaena

alba.

bohlsii.

camura.

darwinii.

fuliginosa

pericensis

plumbea

scutigera.

townsendi

vermicularis

Amphisbaenidae.

Anadia

bitaeniata

Aneuporus occipitalis.

Anguidae

Anisolepis..

argentinus.

bruchi.

iheringii

undulatus

Anolis.

\section{aeneus.}

agassizi

alligator

apollinaris.

auratus.

chrysolepsis

fusco-auratus

jacare.

latifrons .....................

lineatus.

trinitatis

Anopsibaena

kingii.

Aperopristis

catamarcensis

paronae.

Aporomera flavipunctata
Page

26

35

6

6

28

28

28,29

29
Aptycholaenas longicauda ............... 7-9 Argentina ............ 2 . 2, 8, 13-17, 22, 27-28, 36-42

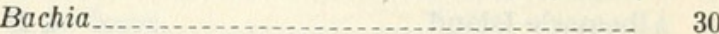

intermedia.......... 30 parkeri .......... 30

Basiliscus ..................... 9 americanus ............................... 9 basiliscus . . . . . . . . 9

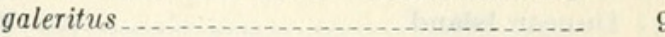

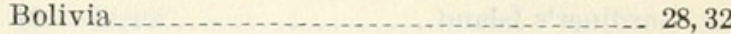
Brazil . .... 3, 7-8, 10, 21, 26-28, 31-32, 34-36, 38, 40-42 British Guiana ................... 30, 35, 38

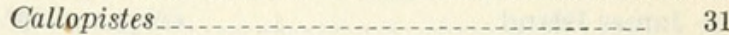
flavipunctatus_......................... 31 maculatus ............................ 31

Calotes chiliensis_.................. 14

Centropyx pelviceps ........ 34

Cercosaura manicata .................... 32

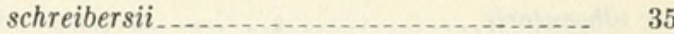
vertebralis_.............................. 33

Chile_............... 15-18, 31 festivus . . . . . .

Cnemidophorus_..................... 31

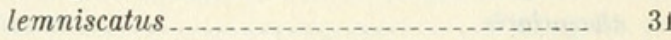
lemniscatus _.......................... 31 murinus _............................. 31 murinus........... 31 praesignis _......................... 29

Colombia_........ 8-10, $12,16,27,29,31,33,37,42$

Craniopeltis bivittata ..................... 23

Diplodactylus gerrhopygus_................. 4

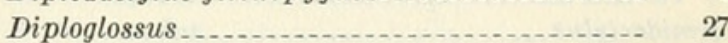
monotropis_.................... 27

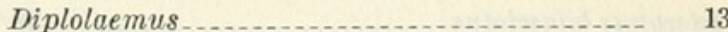

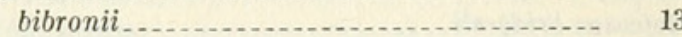

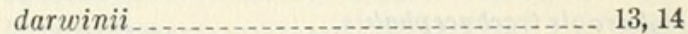

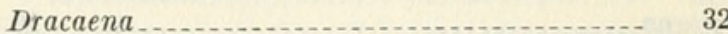
guianensis................................ 32

Dutch Guiana_................... 18-19, 28

Dutch Leeward Islands . . . . . . . . . . . . . . . 5, 5, 31

Ecphymotes obtusirostris undulatus ................................ 7

Ecpleopus luctuosus montium petersi striatus 37

Ecuador _....... 5, 7, 9-10, 12, 21-22. 25, 27, 29, 36, 40

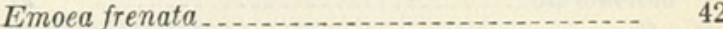

Enyalioides.......... 9

heterolepis............................ 9

laticeps

laticeps

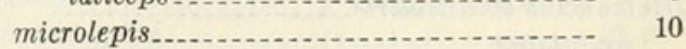


Page

Enyalius ...

heterolepis.......................................

iheringii.

microlepis.

undulatus.

Epaphelus sumichrastii.........................

Euspondylus

maculatus ...............................

ockendeni holmgreni........................ ockendeni.

vertebralis.

Galapagos Archipelago

Abingdon Island.

Albemarle Island....................... 4, 4, 23

Barrington Island ..................... 23

Bindloe Island . . . . . . . . . . . .

Charles Island ........................... 4

Chatham Island...................... 4-5, 23

Daphne Island . . . . . . . . .

Duncan Island . ..................... 6,24

Gardiner's Island .................... 24

Hood Island .................... 4 4,24

Indefatigable Island .................... 23

James Island . ........... , 6

Tower Island ...................................

Gecko mabouia

Gekko rapicauda .

Gekkonidae.

Gonatodes.

albogularis.

atricucullaris

vittatus...

Gorgona Island

Gymnodactylus.

albogularis.

horridus.

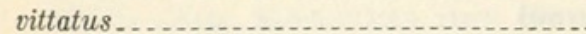

Gymnophthalmus.

laevicaudus.

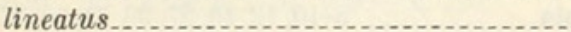

quadrilineatus

sumichrasti.

Hemidactylus ............................... mabouia

Heteropus bifasciatus

Holcosus bridgesii......................

Holotropis trachycephalus.

Iguana

iguana.....

tuberculata

Iguanidae

Kentropyx....

calcaratus.

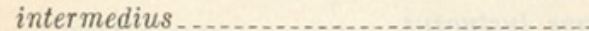

Lacerta ameiva.

igvana..

lineata

marmorata

plica.

quadrilineata.

teguixin.

teyou

Laemanctus obtusirostris.

undulatus.

Lepidoblepharis barbouri.

10

9

10

7

33

32

32

33

33

6

25

3

24

Page

Lepidosternon .......................... 41

boulengeri_................... 41

polystegum_................... 41

scutigerum ............................... 41

Leposternon $\quad 41$

boulengeri......................... 41

microcephalum ........................ 41

polystegum_......................... 41

scutigerum ............................ 41

Leiocephalus _.................... 11, 12

arenarius ..................... 11

caducus_ _...................... 12

ervingi ............................ 11

erythrogaster.......................... 11

iridescens iridescens ..................... 12

lineogularis ............ 11, 12

ornatus .......... 12

ornatus .............. 11, 12

trachycephalus........................ 12

psammodromus ....................... 11

rhodogaster ........................... 11

Leiolaemus bellii ........................... 14

bibronii_.................................. 14

lineatus_.............................. 14

nigromaculatus_...................... 17

Leiosaurus .............................. 13

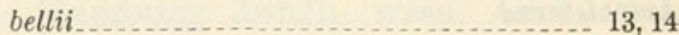

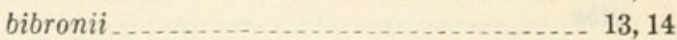

catamarcensis _....................... 13, 14

darwinii_.................. 13, 14

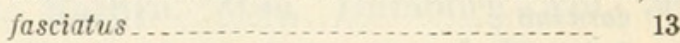

Leposoma buckleyi....................... 35

Liocephalus arenarius _.......................... 11

bolivianus_.................... 12

caducus_.................................. 12

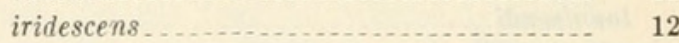

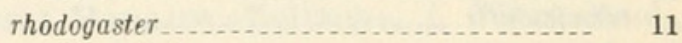

trachycephalus ......................... 12

Liolaemus .................................. 14

annectens_........................ 17

bibronii ............................ 14

catamarcensis........................... 14

chilensis_................................ 14

chiliensis................................. 14

cyanogaster................................... 15

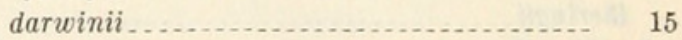

elegans_................................ 16

elongatus .................. 15

fitzingerii ............................... 15

fuscus ................................. 16

hatcheri _... 16

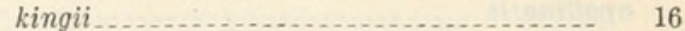

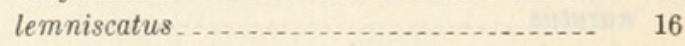

lineomaculatus ........................... 16

multiformis ............................ 17

multiformis . . . . .

simonsii_.............................. $\quad 15$

nigromaculatus

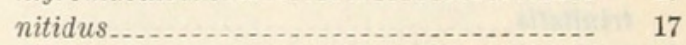

pictus................ 17

pictus................................ 17

tenuis_a.......... 18

wiegmannii_............................. 18

Liosaurus..................................... 13

catamarcensis _............................ 14

darwinii................................. 14 
Page

Mabuya

agilis

dorsovittata

frenata

nigropalmata

Malpelo Island

Microlophus spinulosus

Nicaragua

Norops.

auratus.

Ophiodes

grilli

striatus.

vertebralis.

Oreosaurus

anomalus.

lacertus.

petersii

striatus.

Pantodactylus

bivittatus.

buckleyi buckleyi

festae

schreibersii

Paraguay.

Patagonia

Peru.

Pholidobolus montium

Phyllodactylus.

abrupteseriatus.

baessleri

baruii.

galapagoensis

daphnensis.

gerrhopygus.

guayaquilensis

inaequalis.

leei.

magister

martini

microphyllus.

pulcher.

tuberculosus

Plica

plica

stejnegeri

tuberculatum

umbra.

Polychrus.

acutirostris

femoralis.

marmoratus.

Prionodactylus.

ockendeni.

spinalis.

vertebralis

Pristidactylus

Proctoporus.

anomalus.

bogotensis.

obesus..

ocellifer

pachyurus

petersi.

striatus.
Page

gavreus

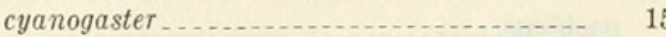

darwinii . .

fitzingerii_............. 15

kingii_.................... 16

multiformis ....................... 17

ornatissimus ............................ 22

pectinatus_........................... 22

pictus _............... 17

tenuis................................... 18

wiegmannii _.......................... 18

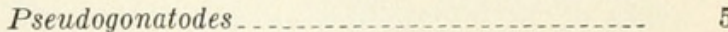

barbouri......................... 5

Ptenodactylus_...

Pygopus striatus ......................... 27

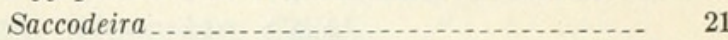

azurea

ornatissima

Scartiscus_..................................... 12

caducus

Scelotrema crassicaudatum

Scincidae_................................. 42

Scincus agilis .............................. 42

monotropis_.................. 27

Seps lineatus _.............................. 34

murinus

South America ........... 6, 9-10, 26-28, 32, 37, 40-41

Stellio torquatus ............................ 27

Stenocercus .............................. 22

boettgeri............................... 22

crassucaudatus............................ 22

ervingi_............................ 11, 22

torquatus ............................. 22

Surinam $\ldots \ldots \ldots \ldots \ldots . .10,21,35,40$

Teiidae

Teius 37

intermedius_............. 35

teyou

teyou ............................... 37

Tejus rufescens .......................... 38

Thecadactylus _........................... 6

rapicaudus........................... 6

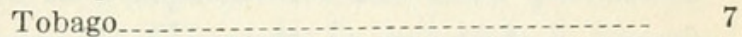

Tretioscincus_.............. 33, 38

bifasciatus .................... 38

laevicaudus. . . . . 33

Trinidad_................. 6-8, 10, 19, 20, 29, 38-40

Tropidocephalus azureus..................... 21

Tropidurus ................. 23

abingdonii ............................ 25

albemarlensis........... 23

albemarlensis.......................... 23

barringtonensis_..................... 23

barringtonensis

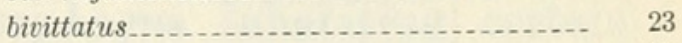

bocourtii

delanonis $\ldots$

duncanensis_.............................. 24

habelii

hoodensis ............................. 24

indefatigabilis ............................ 23

jacobii

lemniscatus . . . . . . 23-24

nigromaculatus_........................ 17 


\section{INDEX}

Tropidurus-Continued.

occipitalis bocourtii occipitalis.

pacificus. habelii.

peruvianus

spinulosus

theresiae.

thomasi.
Page | Tropidurus-Continued. Page

25

25

25

24 25-26

26

torquatus hispidus.

torquatus.

Tupinambis....................... 38

nigropunctatus.................. 38

rufescens_....................... 38

teguixin ..................... 38

Uraniscodon plica ............................. 19

Uruguay . .................. 18, 21, 28, $36-37,39$

Venezuela ............... 2, $6,8,10,20-21,28-31,38$ 


\section{$2 \mathrm{BHL}$ Biodiversity Heritage Library}

Burt, Charles E. and Burt, May Danheim. 1930. "The South American lizards in the collection of the United States National Museum." Proceedings of the United States National Museum 78(2849), 1-52.

https://doi.org/10.5479/si.00963801.2849.

View This Item Online: https://www.biodiversitylibrary.org/item/32389

DOI: https://doi.org/10.5479/si.00963801.2849

Permalink: https://www.biodiversitylibrary.org/partpdf/78703

\section{Holding Institution}

Smithsonian Libraries

\section{Sponsored by}

Smithsonian

\section{Copyright \& Reuse}

Copyright Status: NOT_IN_COPYRIGHT

Rights: https://www.biodiversitylibrary.org/permissions/

This document was created from content at the Biodiversity Heritage Library, the world's largest open access digital library for biodiversity literature and archives. Visit BHL at https://www.biodiversitylibrary.org. 